\title{
Endothelial Dysfunction in Primary Aldosteronism
}

\author{
Zheng-Wei Chen ${ }^{1,2,3}$, Cheng-Hsuan Tsai ${ }^{1,2,4}$, Chien-Ting Pan ${ }^{1,2,3}$, Chia-Hung Chou ${ }^{5}$, \\ Che-Wei Liao ${ }^{6}$, Chi-Sheng Hung ${ }^{1,2}$, Vin-Cent $\mathrm{Wu}^{7}$, Yen-Hung Lin ${ }^{1,2, * \mathbb{B}}$ and \\ TAIPAI Study Group
}

1 Division of Cardiology, Department of Internal Medicine, National Taiwan University Hospital, National Taiwan University College of Medicine, Taipei 10002, Taiwan; librajohn7@hotmail.com (Z.-W.C.); chenghsuan.richard.tsai@gmail.com (C.-H.T.); pan.chienting.m@gmail.com (C.-T.P.); petrehcs@gmail.com (C.-S.H.)

2 Cardiovascular center, National Taiwan University Hospital, Taipei 10002, Taiwan

3 Division of Cardiology, Department of Internal Medicine, National Taiwan University Hospital Yun-Lin Branch, Yun-Lin 64041, Taiwan

4 Division of Cardiology, Department of Internal Medicine, National Taiwan University Hospital Jin-Shan Branch, New Taipei City 20844, Taiwan

5 Department of Obstetrics and Gynecology, National Taiwan University Hospital, National Taiwan University College of Medicine, Taipei 10041, Taiwan; joan640124@yahoo.com.tw

6 Division of Cardiology, Department of Internal Medicine, National Taiwan University Hospital Hsin-Chu Branch, Hsin-Chu 30059, Taiwan; yo.ahliao@gmail.com

7 Division of Nephrology, Department of Internal Medicine, National Taiwan University Hospital, National Taiwan University College of Medicine, Taipei 10002, Taiwan; dr.vincentwu@gmail.com

* Correspondence: austinr34@gmail.com; Tel.: +886-2-2312-3456 (ext. 62152)

Received: 2 September 2019; Accepted: 16 October 2019; Published: 21 October 2019

\begin{abstract}
Primary aldosteronism (PA) is characterized by excess production of aldosterone from the adrenal glands and is the most common and treatable cause of secondary hypertension. Aldosterone is a mineralocorticoid hormone that participates in the regulation of electrolyte balance, blood pressure, and tissue remodeling. The excess of aldosterone caused by PA results in an increase in cardiovascular and cerebrovascular complications, including coronary artery disease, myocardial infarction, stroke, transient ischemic attack, and even arrhythmia and heart failure. Endothelial dysfunction is a well-established fundamental cause of cardiovascular diseases and also a predictor of worse clinical outcomes. Accumulating evidence indicates that aldosterone plays an important role in the initiation and progression of endothelial dysfunction. Several mechanisms have been shown to contribute to aldosterone-induced endothelial dysfunction, including aldosterone-mediated vascular tone dysfunction, aldosterone- and endothelium-mediated vascular inflammation, aldosterone-related atherosclerosis, and vascular remodeling. These mechanisms are activated by aldosterone through genomic and nongenomic pathways in mineralocorticoid receptor-dependent and independent manners. In addition, other cells have also been shown to participate in these mechanisms. The complex interactions among endothelium, inflammatory cells, vascular smooth muscle cells and fibroblasts are crucial for aldosterone-mediated endothelial dysregulation. In this review, we discuss the association between aldosterone and endothelial function and the complex mechanisms from a molecular aspect. Furthermore, we also review current clinical research of endothelial dysfunction in patients with PA.
\end{abstract}

Keywords: primary aldosteronism; endothelial dysfunction; vascular tone; inflammation; vascular remodeling; atherosclerosis; endothelial progenitor cell 


\section{Introduction}

Primary aldosteronism (PA) is now the most common and treatable cause of secondary hypertension [1], with a reported incidence ranging from $5 \%-15 \%$ in hypertensive patients [2]. The aldosterone excess caused by PA leads to greater increases in cardiovascular complications including coronary artery disease, myocardial infarction, stroke, transient ischemic attack, atrial fibrillation and heart failure compared to essential hypertension (EH) [3-9]. In addition, several cardiovascular structural and functional changes are associated with PA, including a higher percentage of left ventricular hypertrophy (LVH) [3], diastolic and subclinical systolic dysfunction [10], and increased arterial wall stiffness [11,12]. Endothelial dysfunction is a well-established fundamental cause of cardiovascular diseases and a predictor of cardiac events [13] and increasing evidence has shown that aldosterone plays an important role in the development of endothelial dysfunction. In current evidence, the effect of aldosterone is largely mediated through the mineralocorticoid receptor (MR). After binding to the MR, the aldosterone-MR complex can further translocate to the nucleus to regulate gene expression (genomic pathway) [14]. Aldosterone may also exert its rapid non-genomic effect independent of transcription or translation in a few minutes. [14]. The non-genomic effect may be mediated by the MR or other receptors (e.g., G protein-coupled estrogen receptor-1 or angiotensin receptor type 1) [14]. In addition, aldosterone can also influence vascular smooth muscle cell and endothelium function without involving MRs, either by aldosterone itself or through other receptors [15]. In this review, we discuss the association between aldosterone and endothelial dysfunction from a molecular aspect of vascular tone, inflammation response, early atherosclerosis and vascular remodeling (Figure 1). We also present an up-to-date review of clinical research on the association between PA and endothelial dysfunction.

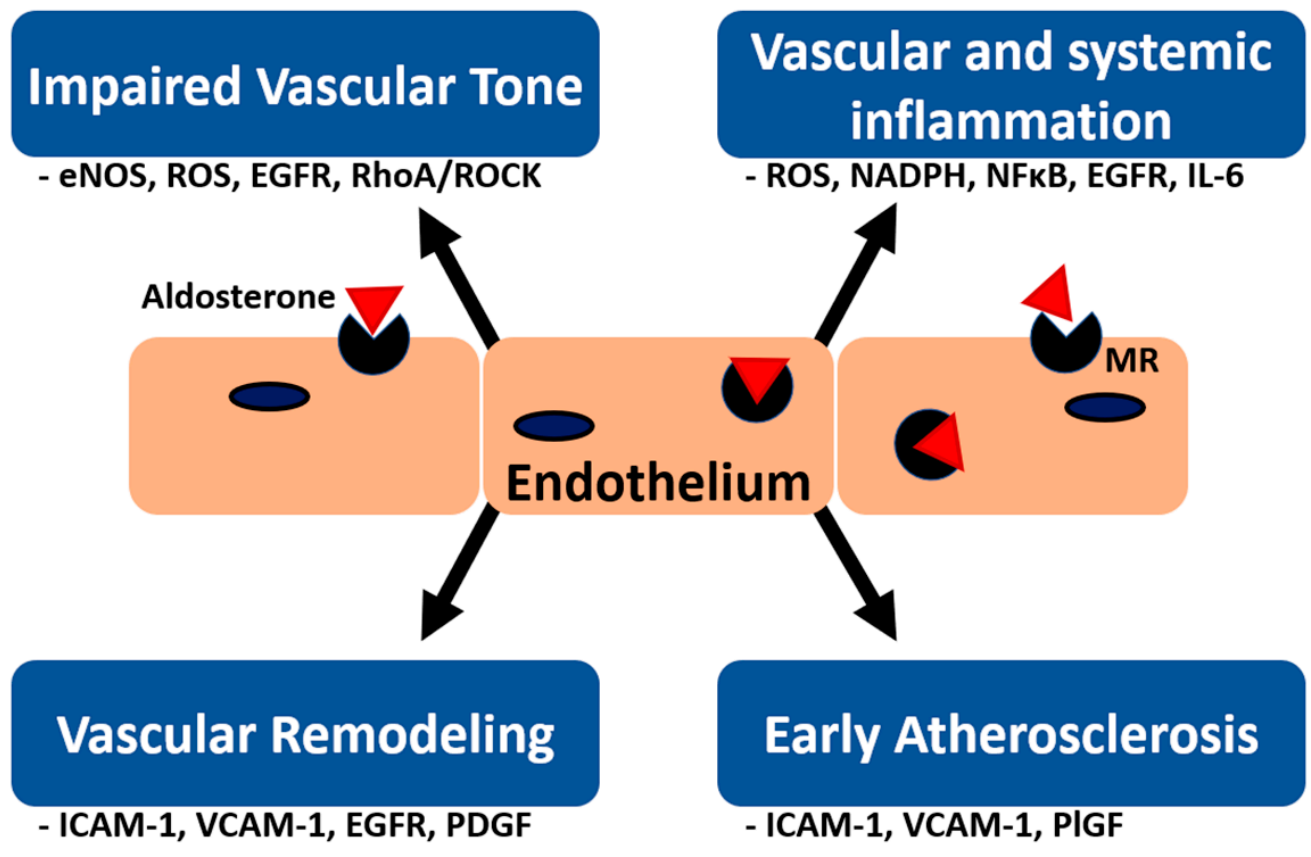

Figure 1. Pathophysiology of aldosterone-induced endothelial dysfunction. There are four major causes of aldosterone-induced endothelial dysfunction including impaired vascular tone, vascular and systemic inflammation, vascular remodeling and early atherosclerosis. $\mathrm{MR}=$ mineralocorticoid receptor; eNOS = endothelial NO synthase; ROS = reactive oxygen species; EGFR = epidermal growth factor receptor; IL = interleukin, $\mathrm{NADPH}=$ nicotinamide adenine dinucleotide phosphate; $\mathrm{ICAM}=$ intercellular adhesion molecule; VCAM = vascular cell adhesion molecule; PDGF = platelet-derived growth factor; and PIGF = placental growth factor. 


\section{Effect of Aldosterone on Vascular Tone}

\subsection{Vasomotor Regulation and the eNOS System}

The endothelium plays an important role in the regulation of cardiovascular function, including vascular tone, vasculature and cellular activity. Nitric oxide (NO) was first reported to be a major endothelium-derived relaxing factor by Furchgott, Ignarro and Murad in the 1980s [16,17]. NO is synthesized from L-arginine in the presence of cofactors including tetrahydrobiopterin (BH4) via endothelial NO synthase (eNOS), which is an enzyme expressed in endothelial cells [18]. Released NO diffuses to vascular smooth muscle cells of the media and regulates vascular tone in three major signaling pathways. First, it activates soluble guanylate cyclase (sGC), which further leads to the formation of cyclic guanosine monophosphate (cGMP) [19]. cGMP activates protein kinase G (PKG), which hinders the calcium influx from voltage-dependent calcium channels (VDCC) and calcium release, and is mediated by inositol 1,4,5-trisphosphate (IP3) receptors [20,21]. PKG also promotes the reuptake of cytosolic calcium into the sarcoplasmic reticulum (SR) via sarco/endoplasmic reticulum calcium ATPase (SERCA). Consequently, the decrease in intracellular calcium concentration and inactivated calmodulin are unable to activate myosin light chain kinase (MLCK), which mediates vasodilation $[22,23]$. Second, under hypoxic status, sGC produces inosine $3^{\prime}, 5^{\prime}$-cyclic monophosphate (cIMP) in some blood vessels (especially coronary arteries) instead of cGMP [24,25], which increases vasoconstriction to hypoxia via increasing Rho-associated protein kinase (ROCK) activity. Third, NO mediates protein S-nitrosylation, including SERCA [26], G protein-coupled receptors (GPCR) [27], beta-arrestin [28] and G protein-coupled receptor kinase 2 (GRK2) [29], to regulate the vasomotor system.

The pathways involved in the activation of eNOS can be classified as being calcium-dependent or -independent. In the calcium-dependent pathway, agonists including acetylcholine [30], bradykinin [31] and histamine [32] activate receptors on the endothelial membrane to increase the intracellular calcium concentration, which then binds to calmodulin to increase eNOS activity [33]. In addition, growth factor, hormone and hemodynamic shear force $[34,35]$ also regulate eNOS through the phosphorylation of different enzyme sites independently of the calcium concentration [36]. Both Ser635 [37] and Ser1177 (or Ser1179) [38] are sites of activation, while Thr495 [39] is inhibitory.

\subsection{Direct Effect of Aldosterone on eNOS System Regulation and NO Production}

Aldosterone influences the vasomotor system through multiple aspects. It causes the deficiency of cofactor $\mathrm{BH} 4$, which leads to uncoupling of eNOS and increased formation of reactive oxygen species (ROS) via a MR-dependent pathway [40]. A previous in vivo study also demonstrated that an adequate $\mathrm{BH} 4$ level is crucial for calcium-dependent $\mathrm{NO}$ formation, and that it regulates the ratio between superoxide and NO [41]. Aldosterone also dephosphorylates eNOS (Ser1177) and further decreases its activity [40]. Moreover, aldosterone itself increases the production of endothelial ROS and reduces ROS scavenging capacity, which further reduces the bioavailability of NO [42].

\subsection{Aldosterone Induces Vasoconstrictors}

Aldosterone increases the formation of vasoconstrictors. In a rat study, chronic aldosterone administration was shown to cause reduced vasodilatation to acetylcholine in the aorta through the activation of cyclooxygenase-2 (COX-2) via prostacyclin in both normotensive and hypertensive groups [43]. A similar effect of chronic aldosterone treatment has also been observed on endothelial function of mesenteric resistance arteries via increasing COX-2-derived prostacyclin and thromboxane A2 [44]. Another rat study also found that endothelin-1 played a role in blood pressure elevation and vascular hypertrophy in aldosterone- and salt-induced hypertension [45]. Endothelin-1 activates $\mathrm{ET}_{\mathrm{A}}$ receptors, and this causes vasoconstriction by impairing endothelial $\mathrm{NO}$ synthesis and its direct vasoconstrictor effect [46]. 


\subsection{Other Pathways Involving Aldosterone-Related Vasomotor Dysregulation}

Aldosterone influences the vasomotor system not only via MR expressed on vascular endothelial and smooth muscle cells, but also via epidermal growth factor receptor (EGFR) and G protein-coupled estrogen receptor (GPER), with downstream mediators such as cyclooxygenase, glucose-6-phosphate dehydrogenase (G6PD) and RhoA/Rho-associated kinase [47].

\subsubsection{EGFR}

Griol-Charhbili et al. first reported the role of the EGFR in endothelial dysfunction [48]. In their genetic mouse model (waved-2 mouse), the partial loss of EGFR tyrosine kinase activity resulted in decreased aldosterone-enhanced vasoconstriction with phenylephrine and angiotensin II, but with no influence on arterial wall remodeling [48].

\subsubsection{GPER}

Recently, Gros et al. proposed a new receptor, which is also involved in rapid non-genomic signaling pathways, GPER (previously known as G protein-coupled receptor 30, GPR30) [49]. GPER is a 7-transmembrane-spanning estrogen receptor that was initially characterized as an estrogen-specific receptor. They also demonstrated that aldosterone causes rapid ERK phosphorylation, which mediates pro-apoptotic and anti-proliferative effects in cultured endothelial cells via GPER activation [50]. Furthermore, they demonstrated that aldosterone-mediated vasodilation was present in isolated vascular ring segments via a GPER signaling pathway [50]. These findings provide a new therapeutic strategy toward GPER pathway to modulate aldosterone-induced endothelial dysfunction.

\subsubsection{G6PD}

Another mechanism of aldosterone-related endothelial dysfunction was proposed by Leopold et al., in which the decreased expression of G6PD regulates vascular function by limiting oxidative stress to preserve NO bioavailability [51]. They demonstrated that aldosterone infusion $\left(10^{-9}\right.$ to $\left.10^{-7} \mathrm{~mol} / \mathrm{L}\right)$ for 12-48 h inhibited G6PD expression in both bovine aortic endothelial cells and human coronary artery endothelial cells. Furthermore, in a mouse model, they also showed that aldosterone impaired endothelial function and vascular G6PD expression, which could then be restored by spironolactone and vascular G6PD gene transfer.

\subsubsection{RhoA/Rho-Associated Kinase Pathway (ROCK)}

The small GTPase RhoA and its mediator Rho kinase are known to be involved in the regulation of cell motility, cell migration and smooth muscle contraction [52]. Increased Rho-associated kinase activity reduces NO bioavailability by inhibiting the expression and activation of eNOS [53], which further impairs vascular tone by unbalancing the production of vasodilators and vasoconstrictors [54]. Matsumoto et al. found lower flow-mediated dilation (FMD) and higher ROCK activity in patients with aldosterone-producing adenoma (APA) compared to those with idiopathic hyperaldosteronism (IHA) and EH [55]. In addition, ROCK activity was correlated with age, plasma aldosterone concentration and aldosterone/renin ratio. Adrenalectomy restored FMD and ROCK activity in the APA patients [55]. Kishimoto et al. also reported that 12 weeks of eplerenone treatment improved vascular function and decreased ROCK activity in IHA patients [56]. As a result, it can be inferred that the ROCK pathway may play a role in vascular function impairment in PA patients.

\subsection{Nongenomic Effects of Aldosterone on Vascular Tones}

With regards to the direct nongenomic effect of aldosterone, Romagni et al. found a rapid vasoconstrictive response to aldosterone $\left(0.9 \mathrm{ng} \cdot \mathrm{min}^{-1}\right)$ in healthy volunteers who had reduced forearm blood flow after acute aldosterone exposure [57]. Another study by Gunaruwan et al. found that local intra-arterial infusion of aldosterone $\left(10,50\right.$, and $\left.100 \mathrm{ng} \cdot \mathrm{min}^{-1}\right)$ showed no acute influence on forearm blood flow and vascular resistance in healthy volunteers [58]. However, Schmidt et al. [59] found 
that forearm blood flow increased under higher concentration aldosterone infusion ( $500 \mathrm{ng} \cdot \mathrm{min}^{-1}$ ) in healthy volunteers. A series of examinations using acetylcholine (testing endothelium-dependent vasodilation), $\mathrm{N}^{\mathrm{G}}$-monomethyl-1-arginine (L-NMMA, testing NO bioavailability), sodium nitroprusside (testing endothelium-independent vasodilation), and phenylephrine (which caused vasoconstriction through $\alpha 1$-adrenoceptors) were performed in that study. They proposed that aldosterone infusion $\left(500 \mathrm{ng} \cdot \mathrm{min}^{-1}\right)$ causes rapid nongenomic effects which included increasing NO release by endothelial cells and promoting vasoconstriction by vascular smooth muscle cells [59]. The diversity of aldosterone responses may be due to its interaction with the adrenergic system [60], differences in the vascular bed and various dosages of aldosterone infusion. Schmitt et al. summarized that vasoconstriction was induced with a lower level of aldosterone, whereas vasodilatation could be found with a higher level of aldosterone [61]. However, further studies are needed to confirm the "real" action of different aldosterone levels on endothelial cells and vascular smooth muscle cells.

\section{Effect of Aldosterone on Endothelium-Mediated Vascular Inflammation}

Chronic low-grade inflammation leads to tissue destruction, proliferation, and fibrosis. Interactions between the cell surface, extracellular matrix, and proinflammatory mediators during inflammatory processes are complex [62]. The endothelium mediates the inflammatory processes through several mechanisms, and the generation of aldosterone-induced ROS plays an important role in the aldosterone mediated endothelium dysfunction $[63,64]$.

\subsection{ROS Systems in Vascular Inflammation}

ROS, including superoxide and hydrogen peroxide, are formed by the univalent reduction of oxygen. This reaction is mediated by several enzyme systems including nicotinamide adenine dinucleotide phosphate (NADPH) oxidases and xanthine oxidase [65]. Aldosterone was shown to increase ROS production and proinflammatory transcription factors such as activator protein (AP)- 1 and nuclear factor kappa B $(\mathrm{NF} \times \mathrm{B})$ in a transgenic rat model [66]. The administration of antioxidant drugs such as the superoxide dismutase mimetic TEMPOL (4-hydroxy-2,2,6,6-tetramethylpiperidinyl-1-oxyl), the NADPH oxidase inhibitor apocynin, and $\mathrm{N}$-acetylcysteine has been shown to decrease inflammation and injury in aldosterone-treated rodents [67-69].

The stimulation of ROS by aldosterone can be explained by several mechanisms. First, aldosterone and MRs play important roles in the production of ROS by NADPH oxidase [40,70]. Second, aldosterone was shown to induce oxidative stress and endothelial dysfunction by decreasing the endothelial expression of G6PD, which then reduced oxidized nicotinamide adenine dinucleotide phosphate to NADPH and thereby increased the accumulation of ROS in aortic endothelial cells in a mice model [51]. Third, the mitochondria are also involved in ROS production. Initially, ROS can open mitochondrial ATP-dependent potassium channels ( mitoK $_{\text {ATP }}$ ), with the subsequent enhanced production of mitochondrial ROS through the electron transport chain as an "ROS-induced ROS release mechanism" [71]. However, the current evidences of aldosterone-induced mitochondrial dysfunction in endothelium are still limited and further studies are required.

The mechanisms involved in aldosterone-induced ROS generation are thought to be via MR-independent and MR-dependent processes. Studies on fibroblasts derived from MR-deficient mice and MR-transfected human embryonic kidney (HEK) cells support the MR-independent mechanism of aldosterone-induced ROS generation via extracellular-signal-regulated kinase (ERK) 1/2, c-Jun N-terminal kinase (JNK) and GPER pathways [49,72,73].

In the NADPH oxidase-related pathway, aldosterone was shown to stimulate the expressions of NADPH oxidase 2 (NOX2/gp91phox) and p22phox through an MR-dependent mechanism and stimulate the expression of p47phox through both angiotensin type 1 (AT1)-receptor-dependent and MR-dependent mechanisms in rat aorta [74]. Leopold et al. reported that the decrease in endothelial GP6D expression caused by aldosterone could be abrogated by an MR antagonist, which also supports that it is an MR-dependent mechanism [51]. The release of ROS from the mitochondria has been speculated to 
be through MR-dependent and non-genomic mechanisms. Aldosterone first activates MR-dependent EGFR transactivation, and then opens mitoK $_{\text {ATP }}$ through the phosphoinositide-3-kinase/protein kinase B (PI3K/Akt) pathway, NO synthase (NOS), and cyclic C-GMP-dependent PKG, which cause the generation of ROS from the mitochondria in the myocardium [71,75].

\subsection{MR-Dependent and-Independent Pathways in Inflammation}

Aldosterone promotes inflammation via MR-dependent and MR-independent mechanisms. Aldosterone and MR activation cause inflammation, fibrosis, and remodeling of the heart and vasculature $[76,77]$.

\subsubsection{MR-Dependent Mechanism}

Several rat model studies have demonstrated that MR activation causes perivascular and interstitial fibrosis in the heart, as well as aortic fibrosis and remodeling [76-80]. Inflammation plays a critical role in initiating fibrosis and remodeling after aldosterone infusion or MR activation. Many antioxidants have been shown to decrease inflammation and injury in rodent models [81-83]. Aldosterone has also been shown to increase oxidative stress in cerebral arteries, which then increases superoxide production, and the mRNA expressions of the pro-inflammatory cytokines chemokine ligand (CCL) 7, CCL8 and interleukin (IL)-1 $\beta$ in the brain. These effects have been shown to be abolished by spironolactone treatment and in endothelial cell MR-deficient mice [84].

High salt intake can potentiate the MR-dependent pathway. Rocha et al. demonstrated the overexpressions of intercellular adhesion molecule (ICAM), COX-2, osteopontin, and monocyte chemoattractant protein (MCP)-1 in an aldosterone-infusion and high salt intake-induced hypertension rat model, and that its effects were abolished by MR blockade [85]. A possible mechanism is that the activation of the Rho family member Rac1, a regulatory subunit of reduced NADPH oxidase, through high salt intake could activate the MR [86]. High salt intake has also been shown to enable the effects of aldosterone on oxidative stress, inflammation, and fibrosis in whole animal models through a potassium-independent mechanism [87].

\subsubsection{MR-Independent Mechanism}

Aldosterone can also exert rapid nongenomic effects that are not blocked by MR inhibitors. GPER plays an important role in the nongenomic effect of aldosterone. Aldosterone has been shown to increase ERK phosphorylation in rat aortic vascular endothelial cells through the GPER pathway [50]. This ERK phosphorylation then increases inflammatory gene expressions and the production of pro-inflammatory cytokines [88]. In addition, ERK1/2 is activated by both aldosterone and angiotensin II. Angiotensin-receptor blockade has been shown to prevent the rapid phosphorylation of ERK1/2 in vascular smooth muscle cells, but not MR inhibitors [89,90]. The interaction between aldosterone and angiotensin II is important with regards to the rapid nongenomic effect. Lemarie et al. [91] demonstrated that the activation of NFKB requires both AT1 receptors and MRs. The activation of ERK1/2 is through AT1 receptors (MR-independent pathway), however the activation of JNK needs both AT1 and MR [91]. The activation of ERK has been shown to result in the expressions of proinflammatory transcription factors such as NFKB, adhesion factors such as ICAM-1, and chemokines such as MCP-1 [92,93].

\subsection{Aldosterone Mediates Interactions between Endothelial and Inflammatory Cells}

Endothelial cells regulate inflammatory cell infiltration and adhesion via an MR-dependent mechanism. Aldosterone increases the expressions of ICAM1, vascular cell adhesion molecule (VCAM)-1 and inflammatory markers such as COX-2 and MCP-1 in the endothelium, which induces monocytes and macrophage infiltration $[85,94,95]$. NFkB induces the production of adhesion molecules and chemokines [93]. MR activation increases ICAM-1 gene transcription, resulting in increased ICAM-1 surface protein and ICAM-1-dependent leukocyte adhesion to human coronary endothelial cells, which has been shown to be inhibited by spironolactone and MR knock-down with small 
interfering RNA [95]. An increased expression of endothelin may also contribute to oxidative stress and increased expression of adhesion molecules during mineralocorticoid excess [96,97]. Jeong et al. also demonstrated that aldosterone stimulated the release of von Willebrand factor (VWF) and IL-18 from human aortic endothelial cells [98]. In addition, aldosterone and MR activation also increase endothelial permeability. Kirsch et al. [99] reported that aldosterone caused a rearrangement of F-actin cytoskeletal fibers in human umbilical vein endothelial cells in MR- and mitogen-activated protein kinase (MAPK)/ERK-dependent mechanisms. The rearrangement of cytoskeletal fibers has been shown to increase permeability to labeled albumin through endothelial cells [99], thereby potentiating immune cell infiltration. The infiltrated monocyte-derived macrophages which are rich in NADPH oxidase then amplify the generation of ROS and worsen vascular inflammation [100]. Furthermore, Dragoni et al. reported that the engagement of ICAM-1 by inflammatory cells or antibodies also activated MAPK pathways including ERK, p38, and JNK in the endothelium, which contributed to the long-term inflammatory response [101].

\subsection{Aldosterone Induces Systemic Inflammation Mediated by the Endothelium}

As a metabolic and endocrine organ, the endothelium actively and reactively participates in hemostasis, growth factors, vascular tone and immune and inflammatory reactions [102,103]. The activation of MRs has been associated with increased systemic inflammatory markers. Our study group demonstrated that aldosterone significantly induces IL-6 protein and mRNA production in human umbilical vein endothelial cells through the MR/PI3K/Akt/NF-kB pathway [104]. Sturgis et al. also demonstrated an increase in plasma IL-6 level in a deoxycorticosterone acetate (DOCA)-salt hypertension mice model [105]. Moreover, Luther et al. reported that circulating IL-6 concentrations increased in humans after $12 \mathrm{~h}$ of aldosterone infusion in healthy volunteers [106]. Our study group found a significant increase in IL-6 in patients with PA compared to patients with EH [104]. In addition, Lim et al. reported that the increase in inflammatory markers related to oxidative stress in PA was associated with diastolic dysfunction [107].

MR antagonists can also help to elucidate the effect of endogenous aldosterone or MR activation on oxidative stress and inflammatory biomarkers. The expressions of systemic inflammatory markers including IL-1 $\beta$, IL- 6 , and the NFKB subunit p105 have been observed in hypertensive rats, and the elevation of inflammatory markers has been shown to be abolished by eplerenone but not by triple antihypertensive agents [108]. These findings suggest that MR-dependent NFKB activation and its downstream actions play important roles in the expression of systemic inflammatory markers.

\section{Effect of Aldosterone on Early Atherosclerosis}

Endothelial dysfunction plays a pivotal role in the development of atherosclerosis [109]. It impairs the vasomotor system and leads to a pro-inflammatory, proliferative, and procoagulatory physiological environment, which then contributes to all stages of atherosclerosis [110]. An increasing number of clinical studies have highlighted the crucial role of aldosterone in the progression of atherosclerosis [111]. The activation of MRs in endothelial cells increases the infiltration of inflammatory cells [112], and these inflammatory cells then promote inflammation and fibrosis. The infiltrated macrophages ingest oxidized low-density lipoproteins and become foam cells, which potentiate the formation of atherosclerosis [113].

The effect of aldosterone on the formation of atherosclerotic plaque has been demonstrated in various studies. In 1995, Van Belle et al. demonstrated that aldosterone enhanced neointimal thickening after balloon denudation in a rabbit model, and that this was inhibited by spironolactone [114]. Keidar et al. demonstrated that aldosterone administration increased macrophage oxidative stress via NADPH oxidase activation and atherosclerotic lesion development in apolipoprotein-E (ApoE) knockout mice, and that the effect could be reduced by eplerenone [115]. Subsequently, Keidar et al. showed that cotreatment with an MR antagonist and tissue angiotensin-converting enzyme (ACE) and/or an angiotensin receptor-1 inhibitor resulted in better blockade of oxidative stress and further reduced the proatherogenic effect [116]. In addition, Suzuki et al. proposed that dual Renin-Angiotensin-Aldosterone system (RAAS) blockade 
with an MR antagonist and ACE inhibitor/angiotensin receptor blocker was more effective than single blockade [117]. Moreover, Imanishi et al. showed that a combination of eplerenone and an ACE inhibitor not only improved NO bioavailability but also decreased atherosclerotic changes in a rabbit model [118]. Taken together, these findings suggest that aldosterone-induced atherosclerosis may, in part, be independent of the angiotensin II pathway.

Marzolla et al. demonstrated the pro-atherogenic effect of aldosterone in ApoE knockout mice via an increased expression of ICAM-1 through endothelial MRs [119]. McGraw et al. also found that aldosterone increased early atherosclerosis and promoted inflammatory plaque in ApoE knockout mice via placental growth factor (PIGF) signaling [120]. PlGF binds to vascular endothelial growth factor (VEGF) type 1 receptors on endothelial and inflammatory cells, and further promotes vascular smooth cell proliferation and monocyte chemotaxis, which are fundamental processes of atherosclerosis.

\section{Effect of Aldosterone on Vascular Remodeling}

Vascular remodeling occurs when the endothelium is insulted, and this pathological response also contributes to vascular ischemic events. The endothelium can be damaged by several conditions, including smoking, diabetes, metabolic syndrome, hypertension, and other mechanical injuries such as balloon angioplasty. Aldosterone promotes vascular remodeling via MR in both vascular smooth cells and endothelial cells [121].

Many previous studies have emphasized the role of aldosterone in vascular remodeling associated with endothelial damage. Wakabayashi et al. demonstrated that eplerenone decreased collagen accumulation and fibrosis, and further inhibited neointimal hyperplasia after coronary stent deployment in a swine model [122]. Pu et al. also showed increased vascular remodeling of small arteries (increased collagen, fibronectin and ICAM-1 in the vessel wall) in aldosterone-treated rats [123]. Both spironolactone and an endothelin antagonist reversed this effect. Lacolley et al. showed increased elastin, collagen and fibronectin in artery walls, implying the structural change of large vessels in rats with hyperaldosteronism [77].

Various mediators participate in MR-related vascular remodeling, including angiotensin II, endothelin-1, EGFR and platelet-derived growth factor (PDGF). Most of these mediators activate receptors located in the walls of vascular smooth muscle cells. The role of vascular smooth muscle cell MRs in vascular remodeling has been well studied and established [121]. In this review, we focused on the functions of endothelial MRs in vascular remodeling.

Nguyen et al. demonstrated the role of endothelial MRs, in which enhanced MR activation in the endothelium increased blood pressure and vascular response to vasoconstrictors independently of MR activation in vascular smooth muscle cells [124]. However, no morphological changes were observed between endothelial cell-specific MR overexpression (ECMROE) mice and littermate control mice. In addition, Schäfer et al. demonstrated that ECMR knockout (ECMRKO) mice did not exhibit endothelial dysfunction induced by aldosterone infusion [125]. Moreover, Rickard et al. found that ECMRKO only reversed endothelial dysfunction caused by aldosterone infusion in large aorta, but not in resistance vessels such as mesenteric arteries [126], which indicated the various functions of ECMRs in different arteries. In this study, the independent role of ECMRs in the aldosterone-induced inflammatory response was observed.

\section{Effect of Aldosterone on Endothelial Progenitor Cells}

Bone marrow-derived endothelial progenitor cells (EPC) play an important role in vascular endothelium repair and serve as a biological marker for vascular function, and even as predictors of cardiovascular risk [127,128].

In 2008, Verhovez et al. demonstrated that the growth characteristics of EPC was not influenced by a high aldosterone level (both EPC from PA patients and in vitro aldosterone-treated EPC from healthy volunteers) [129]. In addition, Thum et al. demonstrated that aldosterone induces the translocation of MRs and impairs EPC function, including differentiation, migration, and proliferation [130]. In a 
mice study, aldosterone impaired EPC homing to vascular structures and vascularization capacity in an MR-dependent manner. In addition, reduced EPC migratory potential was demonstrated in PA patients, which could be reversed by MR blockade. In their study, there were no differences in the number of circulating EPC between a hyperaldosteronism animal model and clinical PA patients compared with control groups. Thum et al. [130] inferred that aldosterone exerts a qualitative rather than quantitative effect on circulating EPC. However, our group showed that PA patients had a lower number of circulating EPC and endothelial colony-forming units compared with EH patients [131]. We also showed that high-dose aldosterone attenuated the proliferation of circulating EPC and impaired angiogenesis. In addition, the decreased number of EPC could be reversed by adrenalectomy or spironolactone treatment. Moreover, we found that the preoperative number of EPC $(\log (\mathrm{EPC}$ number percent) $>-3.6$ ) may be a valuable marker to predict the residual hypertension after adrenalectomy.

\section{Effect of Aldosterone on Ion Channels in Endothelial Cells}

Ion channels are found to be regulated by aldosterone/MR in endothelium and vascular smooth muscle cells [132]. We focus on the ion channels in endothelial cells and summarize their influence on vascular function.

\subsection{Epithelial Sodium Channel}

The epithelial sodium channel $(\mathrm{ENaC})$ was previously known to regulate renal sodium reabsorption and blood pressure control by aldosterone in the distal nephron [133]. However, ENaC had been recently identified in vascular endothelial cells and the expression of $\mathrm{ENaC}$ was enhanced by aldosterone in an MR-dependent manner [134,135]. The up-regulation of ENaC will further cause stiff endothelial cell syndrome accompanied by endothelial dysfunction, which can be inhibited by aldosterone antagonist spironolactone [136]. Jia et al. [137] also showed the role of endothelial ENaC in the aldosterone-induced vascular stiffness and fibrosis in female mice and that the process could be inhibited by epithelial sodium channel antagonist (amiloride). Besides, ENaC $\alpha$-subunit knockout mice also showed attenuated responses to aldosterone infusion [137].

\subsection{Small Conductance Calcium-Activated Potassium Channels}

Other endothelial ion channels regulated by aldosterone/MR are intermediate-conductance KCa3.1 and small-conductance KCa2.3 channels [138]. Small-conductance calcium-activated potassium channels (SKCa) includes three types of channels, KCa2.1, KCa2.2, and KCa2.3, expressed in different tissues [138].

KCa3.1 channels are mainly located on endothelial cell projections traversing the internal elastic lamina. It can be activated by calcium release from endoplasmic reticulum in response to stimulation of muscarinic acetylcholine receptors or other GPCRs [139]. The activation of KCa3.1 channels allows $\mathrm{K}^{+}$to exit endothelial cells and further cause hyperpolarization of nearby vascular smooth muscle cells, which results in vasodilation [140]. KCa2.3 channels are presented in inter-endothelial junctions and co-localize with transient receptor potential channels in the caveolae [141]. KCa2.3 can also be activated by the increase of intracellular calcium induced by acetylcholine or mechanical shear force, and lead to endothelium-derived hyperpolarization and vasorelaxation as well [142].

Taylor et al. demonstrated that the suppression of KCa2.3 in transgenic mice caused significant blood pressure elevation and impaired vascular tone [143]. Köhler et al. also reported that genetic deficiency of KCa3.1 and KCa2.3 both impair endothelium-derived hyperpolarization-related vasodilation in murine models [144]. Also, NO-mediated vasodilation response was compromised in KCa2.3-deficient mice. Both resulted in severe dysregulation of blood pressure control. Previous studies focused on the role of MRs in KCa2.3 expressed on choroidal vasculature. MRA can increase $\mathrm{KCa} 2.3$ protein expression, which causes vasodilation in the eye vasculature [145]. As a result, it may be inferred that MRs regulate KCa2.3 similarly in resistance vessels, which contribute to vascular tone and blood pressure control. This emphasizes the role of vascular SKCa channel in aldosterone-induced endothelial dysfunction, which need further investigation. 


\section{Effect of Aldosterone on Extracellular Vesicles}

Extracellular vesicles (EVs) are released from parent cells into extracellular environment. EVs are biovectors carrying cargo, including protein, enzymes, lipids and RNA, from parent cells [146]. They have gained more and more attention recently for their role in intercellular communication [147]. EVs can be classified as exosomes (40-100 nm), microvesicles (100-1000 nm) and apoptotic bodies (1-5 $\mu \mathrm{m})$ according to their cellular origin, content and particle sizes [148]. EVs can even be biomarkers of several diseases, including, cancer, metabolic disorders, and cardiovascular diseases [149].

In 2012, Lopez et al. found that an increase in circulating EVs is associated with vascular remodeling and endothelial dysfunction in aldosterone-salt-treated rats [150]. Neves et al. also identified endothelial cell-derived microparticles as biomarkers of endothelial injury associated with vascular endothelial growth factor pathway inhibitors (VEGFi) anti-cancer treatment and mediators of endothelin-1 induced pro-inflammatory signaling in endothelial cells, which may contribute to VEGFi-related cardiotoxicity [149]. Besides, EVs directly promote endothelial cell senescence through ROS, causing vascular dysfunction when aging [151].

Recently, Burrello et al. found that PA patients had higher number of endothelium-derived EVs compared with EH patients and normotensive controls [152]. In addition, the number of circulating EVs correlated well with serum aldosterone level. In PA patients receiving unilateral adrenalectomy, the number of EVs decreased significantly [152]. Besides, PA-derived EVs promoted apoptosis and inhibited angiogenesis in vitro. Therefore, the level of circulating EVs may be an indicator of endothelial dysfunction and vascular injury in PA patients. However, whether the increase in EVs was due to the primary effect of aldosterone or aldosterone-induced endothelial dysfunction was not clear [153]. The study by Burrello et al. also showed that the effects of EVs on angiogenesis and apoptosis were likely to result from multiple signaling processes rather than from a single mediator [152].

\section{Clinical Data and Treatment among PA and Endothelial Dysfunction}

In 1993, Taddei et al. demonstrated a reduced vasodilatation effect of acetylcholine in patients with PA and $\mathrm{EH}$, but a similar finding was not observed with the use of nitroprusside [154]. Farquharson et al. showed that short-term aldosterone administration reduced acetylcholine-induced vasodilation measured by forearm venous occlusion plethysmography in healthy young men, which indicates evidence of aldosterone-induced endothelial dysfunction [155]. Farquharson et al. also found that spironolactone improved forearm blood flow response to acetylcholine in chronic heart failure patients [156]. Macdonald et al. showed that endothelial function (acetylcholine-induced vasodilatation), accompanied with brain natriuretic peptide, collagen markers, and QT interval length, improved after spironolactone treatment in patients with asymptomatic or mild heart failure [157].

Previous and recent metanalyses have reported an increased risk of several cardiovascular diseases in PA patients compared to EH controls [3,8]. Endothelial dysfunction has been significantly correlated to several cardiovascular events [13]. Various evaluation tools are used to assess endothelial function, including circulating biomarkers, non-invasive physiological assessment, and invasive physiological assessments in PA patients, with non-invasive physiological tools used most and invasive assessment tools such as forearm venous occlusion plethysmography and cardiac catheterization used less [158-160]. However, no single method currently fully represents the various aspects of vascular endothelial biology, and a combination of different evaluation tools can help clinical researchers to measure endothelial function. Although some of these tests have been commercialized, they are currently reserved for research and to aid in clinical judgment but not for disease diagnosis. Accumulating data from several tests have been reported to be well correlated to further clinical cardiovascular disease outcomes and adverse events [160]. Studies on treatments for PA have also provided data on outcome analysis and the pathogenesis of aldosterone on blood vessels and related treatment responses, which are summarized in Table 1. 
Table 1. Summary of clinical studies on primary aldosteronism and endothelial dysfunction.

\begin{tabular}{|c|c|c|c|c|c|}
\hline Author and Year & Assessment Method & Study Group & Control Group & Treatment & Change and Effect on Endothelial Function \\
\hline \multicolumn{6}{|c|}{ Biomarker } \\
\hline $\begin{array}{l}\text { Verhovez et al. } \\
\text { (2008) [129] }\end{array}$ & Biomarkers: EPC & PA & Healthy control & - & $\begin{array}{l}\text { No difference between high aldosterone treated } \\
\text { EPCs with healthy EPCs }\end{array}$ \\
\hline $\begin{array}{l}\text { Thum et al. (2011) } \\
\text { [130] }\end{array}$ & $\begin{array}{l}\text { Biomarkers: EPC } \\
\text { PAT }\end{array}$ & PA & $\begin{array}{l}\text { Healthy control } \\
\text { Mouse EPCs }\end{array}$ & Spironolactone & $\begin{array}{l}\text { EPCs from PA showed reduced migratory } \\
\text { potential and reduced RHI. } \\
\text { EPCs treated with aldosterone in vitro showed } \\
\text { impaired multiple cellular functions through } \\
\text { MR-dependent pathway. }\end{array}$ \\
\hline $\begin{array}{l}\text { Wu et al. (2011) } \\
\text { [131] }\end{array}$ & $\begin{array}{c}\text { Biomarkers: EPC } \\
\text { PWV }\end{array}$ & PA & $\mathrm{EH}$ & $\begin{array}{l}\text { Adrenalectomy or } \\
\text { spironolactone }\end{array}$ & $\begin{array}{l}\text { Decreased circulating EPCs and endothelial } \\
\text { CFUs, improved after treatment }\end{array}$ \\
\hline $\begin{array}{l}\text { Matrozova et al. } \\
\text { (2016) [161] }\end{array}$ & Biomarkers: ADMA & PA & $\begin{array}{l}\text { EH and healthy } \\
\text { control }\end{array}$ & - & No difference between PA and $\mathrm{EH}$ \\
\hline \multirow{3}{*}{$\begin{array}{c}\text { Liu et al. (2014) } \\
\text { [162] }\end{array}$} & Biomarkers: vWF & PA & $\mathrm{EH}$ & - & Increased \\
\hline & Biomarkers: ICAM-1 & PA & $\mathrm{EH}$ & - & Increased \\
\hline & Biomarkers: ox-LDL & PA & $\mathrm{EH}$ & - & Increased \\
\hline $\begin{array}{l}\text { Chou et al. (2018) } \\
\text { [104] }\end{array}$ & Biomarkers: IL-6 & PA & $\mathrm{EH}$ & Adrenalectomy & $\begin{array}{c}\text { Elevated IL-6 among PA using } \\
\text { mineralocorticoid receptor/PI3K/Akt/NF-kB } \\
\text { pathway }\end{array}$ \\
\hline \multicolumn{6}{|c|}{ FMD/PAT } \\
\hline $\begin{array}{l}\text { Nishizaka et al. } \\
\text { (2004) [163] }\end{array}$ & FMD + NMD & $\begin{array}{l}\text { Resistant hypertension } \\
\text { with hyperaldosteronism }\end{array}$ & $\begin{array}{l}\text { Resistant } \\
\text { hypertension } \\
\text { without } \\
\text { hyperaldosteronism }\end{array}$ & Spironolactone & $\begin{array}{l}\text { Resistant hypertension with } \\
\text { hyperaldosteronism showed lower FMD and } \\
\text { improved after spironolactone. }\end{array}$ \\
\hline $\begin{array}{l}\text { Lai et al. (2016) } \\
\qquad[164]\end{array}$ & FMD & ADPKD with PA & ADPKD without PA & - & ADPKD with PA shows lower FMD. \\
\hline $\begin{array}{l}\text { Chou et al. (2015) } \\
\text { [165] }\end{array}$ & FMD + NMD & PA & $\mathrm{EH}$ & - & $\begin{array}{l}\text { FMD and NMD are both decreased in PA } \\
\text { SERCA2a suppression is observed in vascular } \\
\text { smooth muscle. }\end{array}$ \\
\hline $\begin{array}{l}\text { Matsumoto et al. } \\
\text { (2015) [55] }\end{array}$ & FMD + NMD & $\begin{array}{l}\text { APA } \\
\text { IHA }\end{array}$ & $\mathrm{EH}$ & $\begin{array}{l}\text { Adrenalectomy on } \\
\text { APA }\end{array}$ & $\begin{array}{l}\text { FMD lower in APA than IHA and EH } \\
\text { NMD no significant difference }\end{array}$ \\
\hline
\end{tabular}


Table 1. Cont

\begin{tabular}{|c|c|c|c|c|c|}
\hline Author and Year & Assessment Method & Study Group & Control Group & Treatment & Change and Effect on Endothelial Function \\
\hline $\begin{array}{l}\text { Kishimoto et al. } \\
\text { (2018) [166] }\end{array}$ & $\begin{array}{l}\text { FMD + NMD } \\
\quad \text { PAT }\end{array}$ & $\begin{array}{l}\text { APA } \\
\text { IHA }\end{array}$ & $\mathrm{EH}$ & - & $\begin{array}{c}\text { FMD lower in APA } \\
\text { NMD lower in APA } \\
\text { RHI lower in APA and IHA than EH. }\end{array}$ \\
\hline $\begin{array}{l}\text { Kishimoto et al. } \\
\text { (2019) [56] }\end{array}$ & $\begin{array}{c}\text { FMD + NMD } \\
\text { PAT } \\
\text { PWV }\end{array}$ & IHA & - & Eplerenone & $\begin{array}{c}\text { RHI, NMD improved. } \\
\text { PWV, ROCK activity decreased. } \\
\text { No change in FMD and IMT. }\end{array}$ \\
\hline $\begin{array}{l}\text { Chang et al. (2015) } \\
\text { [167] }\end{array}$ & PAT & PA & $\mathrm{EH}$ & - & $\begin{array}{l}\text { PA had significantly higher AI but not RHI than } \\
\text { EH }\end{array}$ \\
\hline \multicolumn{6}{|c|}{ PWV } \\
\hline $\begin{array}{l}\text { Bernini et al. } \\
\text { (2008) [168] }\end{array}$ & PWV & PA & $\begin{array}{c}\text { EH and } \\
\text { normotensives }\end{array}$ & - & $\begin{array}{l}\text { PA showed more dysfunction and thicker IMT } \\
\text { than EH and normotensives. }\end{array}$ \\
\hline $\begin{array}{l}\text { Strauch et al. } \\
\text { (2006) [169] }\end{array}$ & PWV & PA & $\begin{array}{c}\mathrm{EH} \text { and } \\
\text { normotensives }\end{array}$ & - & $\begin{array}{c}\text { PA showed more dysfunction than } \mathrm{EH} \text { and } \\
\text { normotensives. }\end{array}$ \\
\hline $\begin{array}{l}\text { Strauch et al. } \\
\text { (2008) [170] }\end{array}$ & PWV & $\begin{array}{l}\text { PA receiving } \\
\text { adrenalectomy }\end{array}$ & $\begin{array}{l}\text { PA receiving } \\
\text { spironolactone }\end{array}$ & $\begin{array}{l}\text { Adrenalectomy or } \\
\text { spironolactone }\end{array}$ & $\begin{array}{l}\text { Endothelial dysfunction improved after } \\
\text { adrenalectomy; not seen in spironolactone. }\end{array}$ \\
\hline $\begin{array}{l}\text { Rosa et al. (2012) } \\
\text { [171] }\end{array}$ & PWV & PA & $\mathrm{EH}$ & - & PA showed more dysfunction \\
\hline $\begin{array}{l}\text { Wu et al. (2011) } \\
\text { [131] }\end{array}$ & PWV & PA & $\mathrm{EH}$ & $\begin{array}{l}\text { Adrenalectomy or } \\
\text { spironolactone }\end{array}$ & Increased PWV in PA \\
\hline $\begin{array}{l}\text { Lin et al. (2012) } \\
\text { [11] }\end{array}$ & PWV & $\mathrm{APA}$ & $\mathrm{EH}$ & Adrenalectomy & IMT and dysfunction improved after operation \\
\hline $\begin{array}{l}\text { Liao et al. (2016) } \\
\text { [12] }\end{array}$ & PWV & $\mathrm{APA}$ & - & Adrenalectomy & Dysfunction improved after operation \\
\hline $\begin{array}{l}\text { Chang et al. (2017) } \\
\text { [172] }\end{array}$ & PWV & APA with KCNJ5 (+) & APA with KCNJ5 (-) & Adrenalectomy & - \\
\hline
\end{tabular}

$\mathrm{PA}=$ primary aldosteronism; $\mathrm{EH}=$ essential hypertension; $\mathrm{APA}=$ aldosterone-producing adenoma $\mathrm{IHA}=$ idiopathic hyperaldosteronism; $\mathrm{EPC}=$ endothelial progenitor cells; $\mathrm{PAT}=$ peripheral arterial tonometry; $\mathrm{PWV}=$ pulse wave velocity; $\mathrm{CFUs}=$ colony forming units; $\mathrm{ADMA}=$ asymmetric dimethylarginine; $\mathrm{vWF}=\mathrm{von}$ Willebrand factor; ICAM = intercellular adhesion molecule; ox-LDL = oxidized low-density lipoprotein; IL = interleukin; FMD = flow-mediated vasodilation; NMD = nitrate-mediated dilation; $\mathrm{ADPKD}=$ autosomal dominant polycystic kidney disease; SERCA = sarco/endoplasmic reticulum calcium ATPase; IMT = carotid intima-media thickness; $\mathrm{AI}=$ augmentation index; RHI = reactive hyperemic index and KCNJ5 = potassium voltage-gated channel subfamily J member 5. 


\subsection{Circulating Biomarkers Associated with Endothelial Dysfunction}

Several circulating biomarkers have been studied for endothelial dysfunction, and some have been investigated in PA patients. Asymmetric dimethylarginine (ADMA) has been reported to be a marker of endothelial dysfunction, but it has not been shown to be able to differentiate between PA patients and EH controls [161]. Inflammatory-related adhesion molecules VWF, ICAM-1, and oxidized low-density lipoprotein (ox-LDL) have been found to be significantly higher in PA patients than in EH controls [162]. Our previous study also reported an elevated serum level of the proinflammatory cytokine IL-6 and increased myocardial fibrosis among PA patients and cell studies, and the possible mechanism involved MR/PI3K/Akt/NF-kB pathways [104].

\subsection{Flow-Mediated Dilation (FMD)}

Non-invasive physiological assessments have been frequently used in studies of aldosteronerelated endothelial dysfunction in PA patients. FMD currently remains the technique of choice, and it has become widely used in clinical studies with protocolized guidelines for standardized procedures with good correlations with clinical outcomes with regards to long-term mortality and cardiovascular disease [158-160]. Impaired endothelial dysfunction with decreased FMD has been reported in several clinical studies. Nishizaka et al. demonstrated a strong negative association between an excess of aldosterone and low FMD performance, indicating impaired endothelial function among patients with resistant hypertension later diagnosed with hyperaldosteronism [163]. Autosomal dominant polycystic kidney disease (ADPKD) patients with a higher aldosterone level diagnosed with PA have also been reported to have lower FMD performance [164]. Our previous study demonstrated impaired endothelial function with significantly lower FMD and nitrate-mediated dilation (NMD) in patients with PA than in patients with EH, with impaired vascular smooth muscle cell function and suppressed SERCA 2a expression; the impairment was restored after adrenalectomy [165]. Matsumoto et al. [55] demonstrated a significantly decreased FMD performance among patients with APA, a subtype of PA, compared to patients with idiopathic adrenal hyperplasia (IAH), another subtype of PA, and patients with EH. The decrease in FMD was significantly correlated with increased plasma aldosterone level and ROCK activity, and these parameters were all restored after adrenalectomy [55].

\subsection{Peripheral Arterial Tonometry (PAT) to Evaluate Endothelial Dysfunction}

In addition to FMD reflecting macrovascular endothelial function, reactive hyperemic index (RHI) and augmentation index (AI) performed under peripheral arterial tonometry (PAT) have been shown to indicate microvascular function. RHI measures the change of pulse arterial volume before and after upper arm cuff occlusion, which represents endothelial function; whereas AI measures the relative contribution of augmented pressure due to reflected wave, which indicates arterial stiffness [173]. In conjunction with FMD, differences between patients with different subtypes of PA have provided further clues to the pathogenesis of disease. We previously reported that PA patients had higher arterial stiffness but comparable microvascular endothelial function to EH patients with an increased AI but similar RHI [167]. Kishimoto et al. reported impaired microvascular endothelial function compared to EH patients among PA patients with IAH presenting with a decreased RHI, while PA patients with APA showed decreased RHI and FMD [166]. Matsumoto et al. also reported restored microvascular dysfunction with improved RHI and ROCK activity, and decreased aldosterone-renin ratio after eplerenone treatment in patients with IAH [56]. Different types of endothelial dysfunction are found among PA subtypes, and APA has been attributed to micro- and macrovascular endothelial dysfunction while IAH has been shown to cause microvascular endothelial dysfunction [174].

\subsection{Pulse Wave Velocity (PWV)}

PWV analysis is widely used to evaluate endothelial function based on accumulating data suggesting that endothelial dysfunction is an antecedent of artery stiffening by promoting atherosclerosis 
or vascular muscle contraction [175]. McEniery et al. demonstrated a significant inverse association between PWV and endothelial function assessed by FMD using a large cohort of healthy volunteers who were free of cardiovascular disease, risk factors, and medication [176], Naka et al. also reported the impaired flow-mediated reduction of PWV after endothelium-dependent pharmacological stimuli among heart failure patients compared to healthy controls [177].

Bernini et al. reported both significantly elevated femoral and radial PWV and aortic AI in PA patients compared with EH patients or normotensive controls [168]. Štrauch et al. also reported significantly higher PWV in PA patients compared to EH or normotensive individuals [169], and further reported that decreased PWV and AI were observed among PA patients after adrenalectomy, while no changes were found in those treated with spironolactone [170]. Rosa et al. also demonstrated both elevated peripheral and central PWV among PA patients compared to EH controls, and that this was correlated with plasma aldosterone level [171]. We previously reported increased vascular stiffness and early atherosclerosis presenting as increased PWV and carotid artery thickening in APA patients, and that the change could be reversed by adrenalectomy [11] within 6 months; this was correlated with baseline vascular condition, blood pressure, and hormonal changes [12]. Otherwise, as we know, the potassium voltage-gated channel subfamily J member 5 (KCNJ5) gene is the most common somatic mutation in APA patients, and the KCNJ5 mutation results in loss of potassium and entry of sodium [178]. APA patients with KCNJ5 mutation are younger and have higher aldosterone levels and more severe hypokalemia compared with non-mutant carriers [179]. Although APA patients with KCNJ5 mutation had better hypertension recovery after adrenalectomy, we observed no difference in PWV improvement after adrenalectomy regardless of whether or not the patient had the KCNJ5 mutation [172].

\section{Conclusions}

Endothelial function is crucial to maintain vascular homeostasis, including vascular tone, cellular adhesion, thromboresistance, inflammation and even immunity. The aldosterone excess in PA patients exerts detrimental effects on the endothelium, causing impairment of vascular relaxation, increased oxidative stress, vessel inflammation, vascular remodeling and early atherosclerosis. An in-depth understanding of the pathophysiology of aldosterone-induced endothelial dysfunction may inspire more therapeutic strategies aimed at improving endothelium function in a wide variety of cardiovascular diseases.

Author Contributions: Z.-W.C., C.-H.T., C.-T.P. were responsible for conception, design, draft preparation, and editing of the manuscript; C.-H.C., C.-W.L., C.-S.H., V.-C.W., Y.-H.L. were responsible for review and editing of the manuscript.

Funding: This research received no external funding.

Acknowledgments: Membership of the Taiwan Primary Aldosteronism Investigation (TAIPAI) Study Group: Che-Hsiung Wu, MD (Chi-Taz hospital, PI of Committee); Vin-Cent Wu, MD, PhD (NTUH, PI of Committee); Yen-Hung Lin, MD, PhD (NTUH, PI of Committee); Yi-Luwn Ho, MD, PhD (NTUH, PI of Committee); Hung-Wei Chang, MD, PhD (Far Eastern Hospital, PI of Committee); Lian-Yu Lin MD, PhD (NTUH, PI of Committee); Fu-Chang Hu, MS, ScD, (Harvard Statistics, Site Investigator); Kao-Lang Liu, MD (NTUH, PI of Committee); Shuo-Meng Wang, MD (NTUH, PI of Committee); Kuo-How Huang, MD, PhD (NTUH, PI of Committee); Yung-Ming Chen, MD (NTUH, PI of Committee); Chin-Chi Kuo; MD (Yun-Lin, PI of Committee), Chin-Chen Chang, MD (NTUH, PI of Committee); Shih-Cheng Liao, MD, PhD (NTUH, PI of Committee); Ruoh-Fang Yen, $\mathrm{MD}, \mathrm{PhD}$ (NTUH, PI of Committee); and Kwan-Dun Wu, MD, PhD (NTUH, Director of Coordinating Center).

Conflicts of Interest: The authors declare no conflict of interest.

\section{Abbreviations}

$\begin{array}{ll}\text { PA } & \text { Primary aldosteronism } \\ \text { EH } & \text { Essential hypertension } \\ \text { LVH } & \text { Left ventricular hypertrophy } \\ \text { NO } & \text { Nitric oxide } \\ \text { BH4 } & \text { Tetrahydrobiopterin }\end{array}$




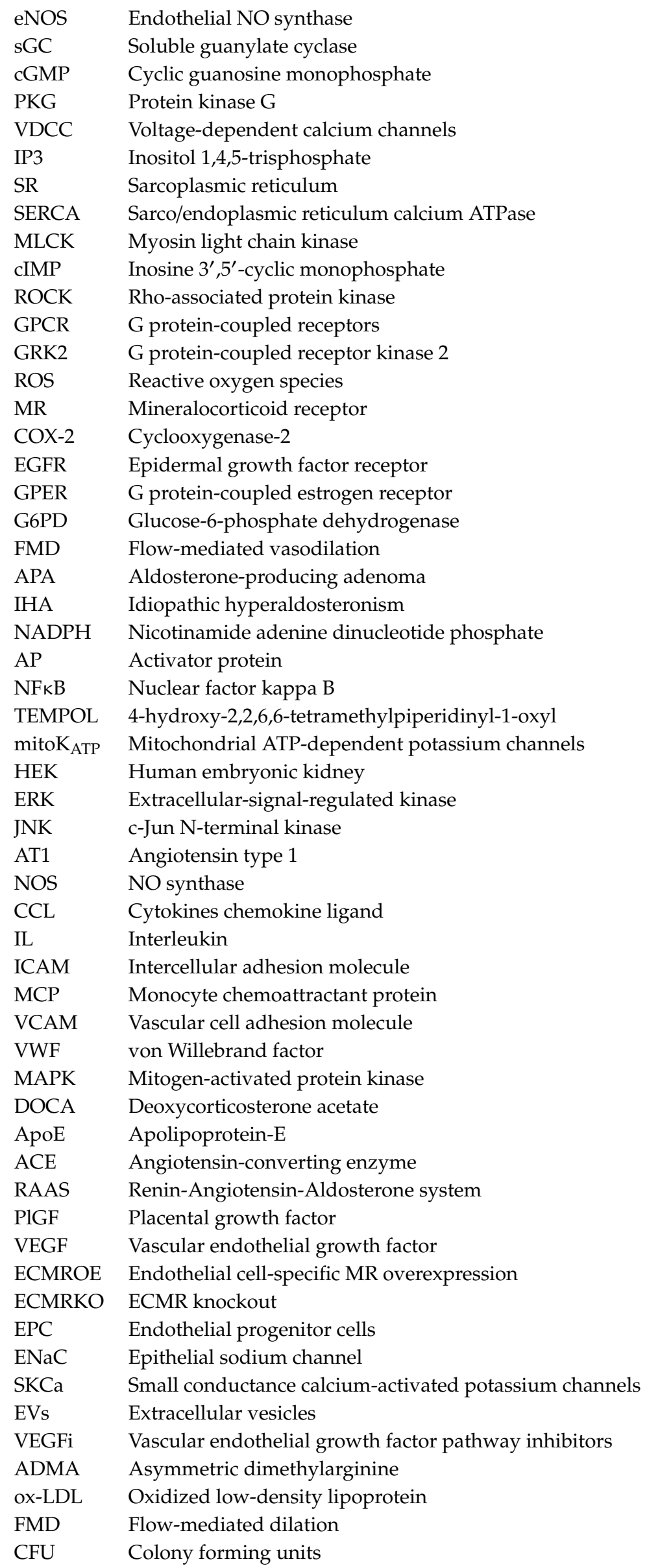




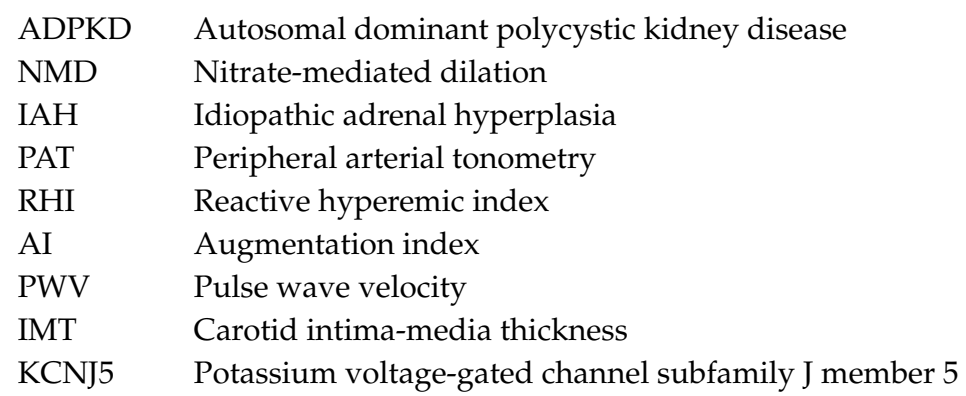

\section{References}

1. Gyamlani, G.; Headley, C.M.; Naseer, A.; Valaulikar, G.S.; Geraci, S.A. Primary aldosteronism: Diagnosis and management. Am. J. Med Sci. 2016, 352, 391-398. [CrossRef] [PubMed]

2. Rossi, G.P. Prevalence and diagnosis of primary aldosteronism. Curr. Hypertens. Rep. 2010, 12, $342-348$. [CrossRef] [PubMed]

3. Milliez, P.; Girerd, X.; Plouin, P.F.; Blacher, J.; Safar, M.E.; Mourad, J.J. Evidence for an increased rate of cardiovascular events in patients with primary aldosteronism. J. Am. Coll. Cardiol. 2005, 45, 1243-1248. [CrossRef] [PubMed]

4. Catena, C.; Colussi, G.; Nadalini, E.; Chiuch, A.; Baroselli, S.; Lapenna, R.; Sechi, L.A. Cardiovascular outcomes in patients with primary aldosteronism after treatment. Arch. Intern. Med. 2008, 168, 80-85. [CrossRef] [PubMed]

5. Reincke, M.; Fischer, E.; Gerum, S.; Merkle, K.; Schulz, S.; Pallauf, A.; Quinkler, M.; Hanslik, G.; Lang, K.; Hahner, S.; et al. Observational study mortality in treated primary aldosteronism: The german conn's registry. Hypertension 2012, 60, 618-624. [CrossRef] [PubMed]

6. Savard, S.; Amar, L.; Plouin, P.F.; Steichen, O. Cardiovascular complications associated with primary aldosteronism: A controlled cross-sectional study. Hypertension 2013, 62, 331-336. [CrossRef] [PubMed]

7. Mulatero, P.; Monticone, S.; Bertello, C.; Viola, A.; Tizzani, D.; Iannaccone, A.; Crudo, V.; Burrello, J.; Milan, A.; Rabbia, F.; et al. Long-term cardio- and cerebrovascular events in patients with primary aldosteronism. J. Clin. Endocrinol. Metab. 2013, 98, 4826-4833. [CrossRef]

8. Monticone, S.; D’Ascenzo, F.; Moretti, C.; Williams, T.A.; Veglio, F.; Gaita, F.; Mulatero, P. Cardiovascular events and target organ damage in primary aldosteronism compared with essential hypertension: A systematic review and meta-analysis. Lancet. Diabetes Endocrinol. 2018, 6, 41-50. [CrossRef]

9. Wu, V.C.; Wang, S.M.; Chang, C.H.; Hu, Y.H.; Lin, L.Y.; Lin, Y.H.; Chueh, S.C.; Chen, L.; Wu, K.D. Long term outcome of aldosteronism after target treatments. Sci. Rep. 2016, 6, 32103. [CrossRef]

10. Chen, Z.W.; Huang, K.C.; Lee, J.K.; Lin, L.C.; Chen, C.W.; Chang, Y.Y.; Liao, C.W.; Wu, V.C.; Hung, C.S.; Lin, Y.H.; et al. Aldosterone induces left ventricular subclinical systolic dysfunction: A strain imaging study. J. Hypertens. 2018, 36, 353-360. [CrossRef]

11. Lin, Y.-H.; Lin, L.-Y.; Chen, A.; Wu, X.-M.; Lee, J.-K.; Su, T.-C.; Wu, V.-C.; Chueh, S.-C.; Lin, W.-C.; Lo, M.-T.; et al. Adrenalectomy improves increased carotid intima-media thickness and arterial stiffness in patients with aldosterone producing adenoma. Atherosclerosis 2012, 221, 154-159. [CrossRef] [PubMed]

12. Liao, C.W.; Lin, L.Y.; Hung, C.S.; Lin, Y.T.; Chang, Y.Y.; Wang, S.M.; Wu, V.C.; Wu, K.D.; Ho, Y.L.; Satoh, F.; et al. Time course and factors predicting arterial stiffness reversal in patients with aldosterone-producing adenoma after adrenalectomy: Prospective study of 102 patients. Sci. Rep. 2016, 6, 20862. [CrossRef] [PubMed]

13. Lerman, A.; Zeiher, A.M. Endothelial function: Cardiac events. Circulation 2005, 111, 363-368. [CrossRef] [PubMed]

14. Hermidorff, M.M.; de Assis, L.V.; Isoldi, M.C. Genomic and rapid effects of aldosterone: What we know and do not know thus far. Heart Fail. Rev. 2017, 22, 65-89. [CrossRef] [PubMed]

15. Mihailidou, A.S.; Tzakos, A.G.; Ashton, A.W. Non-genomic effects of aldosterone. Vitam. Horm. 2019, 109, 133-149. [PubMed] 
16. Furchgott, R.F. The 1996 albert lasker medical research awards. The discovery of endothelium-derived relaxing factor and its importance in the identification of nitric oxide. JAMA 1996, 276, 1186-1188. [CrossRef] [PubMed]

17. Murad, F. Nitric oxide and cyclic gmp in cell signaling and drug development. New Engl. J. Med. 2006, 355, 2003-2011. [CrossRef]

18. Forstermann, U.; Munzel, T. Endothelial nitric oxide synthase in vascular disease: From marvel to menace. Circulation 2006, 113, 1708-1714. [CrossRef]

19. Derbyshire, E.R.; Marletta, M.A. Structure and regulation of soluble guanylate cyclase. Annu. Rev. Biochem. 2012, 81, 533-559. [CrossRef]

20. Carvajal, J.A.; Germain, A.M.; Huidobro-Toro, J.P.; Weiner, C.P. Molecular mechanism of cgmp-mediated smooth muscle relaxation. J. Cell. Physiol. 2000, 184, 409-420. [CrossRef]

21. Cohen, R.A.; Weisbrod, R.M.; Gericke, M.; Yaghoubi, M.; Bierl, C.; Bolotina, V.M. Mechanism of nitric oxide-induced vasodilatation. Circ. Res. 1999, 84, 210-219. [CrossRef] [PubMed]

22. Lee, M.R.; Li, L.; Kitazawa, T. Cyclic gmp causes Ca2+ desensitization in vascular smooth muscle by activating the myosin light chain phosphatase. J. Biol. Chem. 1997, 272, 5063-5068. [CrossRef] [PubMed]

23. Mizuno, Y.; Isotani, E.; Huang, J.; Ding, H.; Stull, J.T.; Kamm, K.E. Myosin light chain kinase activation and calcium sensitization in smooth muscle in vivo. Am. J. Physiol. Cell Physiol. 2008, 295, C358-C364. [CrossRef] [PubMed]

24. Chen, Z.; Zhang, X.; Ying, L.; Dou, D.; Li, Y.; Bai, Y.; Liu, J.; Liu, L.; Feng, H.; Yu, X.; et al. Cimp synthesized by sgc as a mediator of hypoxic contraction of coronary arteries. Am. J. Physiol. Heart Circ. Physiol. 2014, 307, H328-H336. [CrossRef]

25. Gao, Y.; Chen, Z.; Leung, S.W.; Vanhoutte, P.M. Hypoxic vasospasm mediated by cimp: When soluble guanylyl cyclase turns bad. J. Cardiovasc. Pharmacol. 2015, 65, 545-548. [CrossRef]

26. Adachi, T.; Weisbrod, R.M.; Pimentel, D.R.; Ying, J.; Sharov, V.S.; Schöneich, C.; Cohen, R.A. S-glutathiolation by peroxynitrite activates serca during arterial relaxation by nitric oxide. Nat. Med. 2004, 10, 1200-1207. [CrossRef]

27. Daaka, Y. S-nitrosylation-regulated gpcr signaling. Biochim. Et Biophys. Acta (Bba) Gen. Subj. 2012, 1820, 743-751. [CrossRef]

28. Ozawa, K.; Whalen, E.J.; Nelson, C.D.; Mu, Y.; Hess, D.T.; Lefkowitz, R.J.; Stamler, J.S. S-nitrosylation of $\beta$-arrestin regulates $\beta$-adrenergic receptor trafficking. Mol. Cell 2008, 31, 395-405. [CrossRef]

29. Whalen, E.J.; Foster, M.W.; Matsumoto, A.; Ozawa, K.; Violin, J.D.; Que, L.G.; Nelson, C.D.; Benhar, M.; Keys, J.R.; Rockman, H.A.; et al. Regulation of $\beta$-adrenergic receptor signaling by s-nitrosylation of g-protein-coupled receptor kinase 2. Cell 2007, 129, 511-522. [CrossRef]

30. Kellogg, D.L., Jr.; Zhao, J.L.; Coey, U.; Green, J.V. Acetylcholine-induced vasodilation is mediated by nitric oxide and prostaglandins in human skin. J. Appl. Physiol. 2005, 98, 629-632. [CrossRef]

31. Bae, S.W.; Kim, H.S.; Cha, Y.N.; Park, Y.S.; Jo, S.A.; Jo, I. Rapid increase in endothelial nitric oxide production by bradykinin is mediated by protein kinase a signaling pathway. Biochem. Biophys. Res. Commun. 2003, 306, 981-987. [CrossRef]

32. Li, H.; Burkhardt, C.; Heinrich, U.-R.; Brausch, I.; Xia, N.; Förstermann, U. Histamine upregulates gene expression of endothelial nitric oxide synthase in human vascular endothelial cells. Circulation 2003, 107, 2348-2354. [CrossRef] [PubMed]

33. Kuchan, M.J.; Frangos, J.A. Role of calcium and calmodulin in flow-induced nitric oxide production in endothelial cells. Am. J. Physiol. Cell Physiol. 1994, 266, C628-C636. [CrossRef] [PubMed]

34. Andrews, A.M.; Jaron, D.; Buerk, D.G.; Kirby, P.L.; Barbee, K.A. Direct, real-time measurement of shear stress-induced nitric oxide produced from endothelial cells in vitro. Nitric Oxide 2010, 23, 335-342. [CrossRef] [PubMed]

35. Harrison, D.G.; Widder, J.; Grumbach, I.; Chen, W.; Weber, M.; Searles, C. Endothelial mechanotransduction, nitric oxide and vascular inflammation. J. Intern. Med. 2006, 259, 351-363. [CrossRef] [PubMed]

36. Sessa, W.C. Enos at a glance. J. Cell Sci. 2004, 117, 2427-2429. [CrossRef]

37. Boo, Y.C.; Hwang, J.; Sykes, M.; Michell, B.J.; Kemp, B.E.; Lum, H.; Jo, H. Shear stress stimulates phosphorylation of enos at ser635 by a protein kinase a-dependent mechanism. Am. J. Physiol. Heart Circ. Physiol. 2002, 283, H1819-H1828. [CrossRef] 
38. Boo, Y.C.; Sorescu, G.; Boyd, N.; Shiojima, I.; Walsh, K.; Du, J.; Jo, H. Shear stress stimulates phosphorylation of endothelial nitric-oxide synthase at ser1179 by akt-independent mechanisms: Role of protein kinase a. J. Biol. Chem. 2002, 277, 3388-3396. [CrossRef]

39. Fleming, I.; Fisslthaler, B.; Dimmeler, S.; Kemp, B.E.; Busse, R. Phosphorylation of thr(495) regulates $\mathrm{ca}(2+) /$ calmodulin-dependent endothelial nitric oxide synthase activity. Circ. Res. 2001, 88, E68-E75. [CrossRef]

40. Nagata, D.; Takahashi, M.; Sawai, K.; Tagami, T.; Usui, T.; Shimatsu, A.; Hirata, Y.; Naruse, M. Molecular mechanism of the inhibitory effect of aldosterone on endothelial no synthase activity. Hypertension 2006, 48, 165-171. [CrossRef]

41. Vasquez-Vivar, J.; Kalyanaraman, B.; Martasek, P.; Hogg, N.; Masters, B.S.; Karoui, H.; Tordo, P.; Pritchard, K.A., Jr. Superoxide generation by endothelial nitric oxide synthase: The influence of cofactors. Proc. Natl. Acad. Sci. USA 1998, 95, 9220-9225. [CrossRef] [PubMed]

42. Cachofeiro, V.; Miana, M.; de las Heras, N.; Martín-Fernández, B.; Ballesteros, S.; Fernández-Tresguerres, J.; Lahera, V. Aldosterone and the vascular system. J. Steroid Biochem. Mol. Biol. 2008, 109, 331-335. [CrossRef] [PubMed]

43. Blanco-Rivero, J.; Cachofeiro, V.; Lahera, V.; Aras-Lopez, R.; Marquez-Rodas, I.; Salaices, M.; Xavier, F.E.; Ferrer, M.; Balfagon, G. Participation of prostacyclin in endothelial dysfunction induced by aldosterone in normotensive and hypertensive rats. Hypertension 2005, 46, 107-112. [CrossRef] [PubMed]

44. Xavier, F.E.; Aras-Lopez, R.; Arroyo-Villa, I.; del Campo, L.; Salaices, M.; Rossoni, L.V.; Ferrer, M.; Balfagon, G. Aldosterone induces endothelial dysfunction in resistance arteries from normotensive and hypertensive rats by increasing thromboxane a2 and prostacyclin. Br. J. Pharmacol. 2008, 154, 1225-1235. [CrossRef]

45. Park, J.B.; Schiffrin, E.L. Et(a) receptor antagonist prevents blood pressure elevation and vascular remodeling in aldosterone-infused rats. Hypertension 2001, 37, 1444-1449. [CrossRef]

46. Bourque, S.L.; Davidge, S.T.; Adams, M.A. The interaction between endothelin-1 and nitric oxide in the vasculature: New perspectives. Am. J. Physiol. Regul. Integr. Comp. Physiol. 2011, 300, R1288-R1295. [CrossRef]

47. Briet, M.; Schiffrin, E.L. Vascular actions of aldosterone. J. Vasc. Res. 2013, 50, 89-99. [CrossRef]

48. Griol-Charhbili, V.; Fassot, C.; Messaoudi, S.; Perret, C.; Agrapart, V.; Jaisser, F. Epidermal growth factor receptor mediates the vascular dysfunction but not the remodeling induced by aldosterone/salt. Hypertension 2011, 57, 238-244. [CrossRef]

49. Gros, R.; Ding, Q.; Sklar, L.A.; Prossnitz, E.E.; Arterburn, J.B.; Chorazyczewski, J.; Feldman, R.D. Gpr30 expression is required for the mineralocorticoid receptor-independent rapid vascular effects of aldosterone. Hypertension 2011, 57, 442-451. [CrossRef]

50. Gros, R.; Ding, Q.; Liu, B.; Chorazyczewski, J.; Feldman, R.D. Aldosterone mediates its rapid effects in vascular endothelial cells through gper activation. Am. J. Physiol. Cell Physiol. 2013, 304, C532-C540. [CrossRef]

51. Leopold, J.A.; Dam, A.; Maron, B.A.; Scribner, A.W.; Liao, R.; Handy, D.E.; Stanton, R.C.; Pitt, B.; Loscalzo, J. Aldosterone impairs vascular reactivity by decreasing glucose-6-phosphate dehydrogenase activity. Nat. Med. 2007, 13, 189-197. [CrossRef] [PubMed]

52. Riento, K.; Ridley, A.J. Rocks: Multifunctional kinases in cell behaviour. Nat. Rev. Mol. Cell Biol. 2003, 4, 446-456. [CrossRef] [PubMed]

53. Hassona, M.D.; Abouelnaga, Z.A.; Elnakish, M.T.; Awad, M.M.; Alhaj, M.; Goldschmidt-Clermont, P.J.; Hassanain, H. Vascular hypertrophy-associated hypertension of profilin1 transgenic mouse model leads to functional remodeling of peripheral arteries. Am. J. Physiol. Heart Circ. Physiol. 2010, 298, H2112-H2120. [CrossRef] [PubMed]

54. Yao, L.; Romero, M.J.; Toque, H.A.; Yang, G.; Caldwell, R.B.; Caldwell, R.W. The role of rhoa/rho kinase pathway in endothelial dysfunction. J. Cardiovasc. Dis. Res. 2010, 1, 165-170. [PubMed]

55. Matsumoto, T.; Oki, K.; Kajikawa, M.; Nakashima, A.; Maruhashi, T.; Iwamoto, Y.; Iwamoto, A.; Oda, N.; Hidaka, T.; Kihara, Y.; et al. Effect of aldosterone-producing adenoma on endothelial function and rho-associated kinase activity in patients with primary aldosteronism. Hypertension 2015, 65, 841-848. [CrossRef] [PubMed]

56. Kishimoto, S.; Oki, K.; Maruhashi, T.; Kajikawa, M.; Matsui, S.; Hashimoto, H.; Takaeko, Y.; Kihara, Y.; Chayama, K.; Goto, C.; et al. Eplerenone improves endothelial function and arterial stiffness and inhibits rho-associated kinase activity in patients with idiopathic hyperaldosteronism: A pilot study. J. Hypertens. 2019, 37, 1083-1095. [CrossRef] 
57. Romagni, P.; Rossi, F.; Guerrini, L.; Quirini, C.; Santiemma, V. Aldosterone induces contraction of the resistance arteries in man. Atherosclerosis 2003, 166, 345-349. [CrossRef]

58. Gunaruwan, P.; Schmitt, M.; Taylor, J.; Lee, L.; Struthers, A.; Frenneaux, M. Lack of rapid aldosterone effects on forearm resistance vasculature in health. J. Renin-Angiotensin-Aldosterone Syst. JRAAS 2002, 3, 123-125. [CrossRef]

59. Schmidt, B.M.W.; Oehmer, S.; Delles, C.; Bratke, R.; Schneider, M.P.; Klingbeil, A.; Fleischmann, E.H.; Schmieder, R.E. Rapid nongenomic effects of aldosterone on human forearm vasculature. Hypertension 2003, 42, 156-160. [CrossRef]

60. Schmidt, B.M.; Georgens, A.C.; Martin, N.; Tillmann, H.C.; Feuring, M.; Christ, M.; Wehling, M. Interaction of rapid nongenomic cardiovascular aldosterone effects with the adrenergic system. J. Clin. Endocrinol. Metab. 2001, 86, 761-767. [CrossRef]

61. Schmitt, M.; Gunaruwan, P.; Frenneaux, M.P. Rapid nongenomic aldosterone effects in the human forearm? Hypertension 2004, 43, e1, author reply e2. [CrossRef] [PubMed]

62. Keane, M.P.; Strieter, R.M. Chemokine signaling in inflammation. Crit. Care Med. 2000, 28, N13-N26. [CrossRef] [PubMed]

63. Chrissobolis, S.; Drummond, G.R.; Faraci, F.M.; Sobey, C.G. Chronic aldosterone administration causes nox2-mediated increases in reactive oxygen species production and endothelial dysfunction in the cerebral circulation. J. Hypertens. 2014, 32, 1815-1821. [CrossRef] [PubMed]

64. Iwashima, F.; Yoshimoto, T.; Minami, I.; Sakurada, M.; Hirono, Y.; Hirata, Y. Aldosterone induces superoxide generation via rac1 activation in endothelial cells. Endocrinology 2008, 149, 1009-1014. [CrossRef] [PubMed]

65. Taniyama, Y.; Griendling, K.K. Reactive oxygen species in the vasculature: Molecular and cellular mechanisms. Hypertension 2003, 42, 1075-1081. [CrossRef] [PubMed]

66. Fiebeler, A.; Schmidt, F.; Muller, D.N.; Park, J.K.; Dechend, R.; Bieringer, M.; Shagdarsuren, E.; Breu, V.; Haller, H.; Luft, F.C. Mineralocorticoid receptor affects ap-1 and nuclear factor-kappab activation in angiotensin ii-induced cardiac injury. Hypertension 2001, 37, 787-793. [CrossRef]

67. Sun, Y.; Zhang, J.; Lu, L.; Chen, S.S.; Quinn, M.T.; Weber, K.T. Aldosterone-induced inflammation in the rat heart: Role of oxidative stress. Am. J. Pathol. 2002, 161, 1773-1781. [CrossRef]

68. Iglarz, M.; Touyz, R.M.; Viel, E.C.; Amiri, F.; Schiffrin, E.L. Involvement of oxidative stress in the profibrotic action of aldosterone. Interaction wtih the renin-angiotension system. Am. J. Hypertens. 2004, 17, 597-603. [CrossRef]

69. Park, Y.M.; Park, M.Y.; Suh, Y.L.; Park, J.B. Nad(p)h oxidase inhibitor prevents blood pressure elevation and cardiovascular hypertrophy in aldosterone-infused rats. Biochem. Biophys. Res. Commun. 2004, 313, 812-817. [CrossRef]

70. Datla, S.R.; Griendling, K.K. Reactive oxygen species, nadph oxidases, and hypertension. Hypertension 2010, 56, 325-330. [CrossRef]

71. Nolly, M.B.; Caldiz, C.I.; Yeves, A.M.; Villa-Abrille, M.C.; Morgan, P.E.; Amado Mondaca, N.; Portiansky, E.L.; Chiappe de Cingolani, G.E.; Cingolani, H.E.; Ennis, I.L. The signaling pathway for aldosterone-induced mitochondrial production of superoxide anion in the myocardium. J. Mol. Cell Cardiol. 2014, 67, 60-68. [CrossRef] [PubMed]

72. Haseroth, K.; Gerdes, D.; Berger, S.; Feuring, M.; Gunther, A.; Herbst, C.; Christ, M.; Wehling, M. Rapid nongenomic effects of aldosterone in mineralocorticoid-receptor-knockout mice. Biochem. Biophys. Res. Commun. 1999, 266, 257-261. [CrossRef] [PubMed]

73. Grossmann, C.; Benesic, A.; Krug, A.W.; Freudinger, R.; Mildenberger, S.; Gassner, B.; Gekle, M. Human mineralocorticoid receptor expression renders cells responsive for nongenotropic aldosterone actions. Mol. Endocrinol. 2005, 19, 1697-1710. [CrossRef] [PubMed]

74. Hirono, Y.; Yoshimoto, T.; Suzuki, N.; Sugiyama, T.; Sakurada, M.; Takai, S.; Kobayashi, N.; Shichiri, M.; Hirata, Y. Angiotensin ii receptor type 1-mediated vascular oxidative stress and proinflammatory gene expression in aldosterone-induced hypertension: The possible role of local renin-angiotensin system. Endocrinology 2007, 148, 1688-1696. [CrossRef]

75. Downey, J.M.; Krieg, T.; Cohen, M.V. Mapping preconditioning's signaling pathways: An engineering approach. Ann. N. Y. Acad. Sci. 2008, 1123, 187-196. [CrossRef]

76. Brilla, C.G.; Matsubara, L.S.; Weber, K.T. Anti-aldosterone treatment and the prevention of myocardial fibrosis in primary and secondary hyperaldosteronism. J. Mol. Cell Cardiol. 1993, 25, 563-575. [CrossRef] 
77. Lacolley, P.; Labat, C.; Pujol, A.; Delcayre, C.; Benetos, A.; Safar, M. Increased carotid wall elastic modulus and fibronectin in aldosterone-salt-treated rats: Effects of eplerenone. Circulation 2002, 106, 2848-2853. [CrossRef]

78. Brilla, C.G.; Weber, K.T. Mineralocorticoid excess, dietary sodium, and myocardial fibrosis. J. Lab. Clin. Med. 1992, 120, 893-901.

79. Young, M.; Fullerton, M.; Dilley, R.; Funder, J. Mineralocorticoids, hypertension, and cardiac fibrosis. J. Clin. Investig. 1994, 93, 2578-2583. [CrossRef]

80. Benetos, A.; Lacolley, P.; Safar, M.E. Prevention of aortic fibrosis by spironolactone in spontaneously hypertensive rats. Arterioscler. Thromb. Vasc. Biol. 1997, 17, 1152-1156. [CrossRef]

81. Matsui, H.; Ando, K.; Kawarazaki, H.; Nagae, A.; Fujita, M.; Shimosawa, T.; Nagase, M.; Fujita, T. Salt excess causes left ventricular diastolic dysfunction in rats with metabolic disorder. Hypertension 2008, 52, 287-294. [CrossRef]

82. Yoshida, K.; Kim-Mitsuyama, S.; Wake, R.; Izumiya, Y.; Izumi, Y.; Yukimura, T.; Ueda, M.; Yoshiyama, M.; Iwao, H. Excess aldosterone under normal salt diet induces cardiac hypertrophy and infiltration via oxidative stress. Hypertens. Res. 2005, 28, 447-455. [CrossRef] [PubMed]

83. Rude, M.K.; Duhaney, T.A.; Kuster, G.M.; Judge, S.; Heo, J.; Colucci, W.S.; Siwik, D.A.; Sam, F. Aldosterone stimulates matrix metalloproteinases and reactive oxygen species in adult rat ventricular cardiomyocytes. Hypertension 2005, 46, 555-561. [CrossRef] [PubMed]

84. Dinh, Q.N.; Young, M.J.; Evans, M.A.; Drummond, G.R.; Sobey, C.G.; Chrissobolis, S. Aldosterone-induced oxidative stress and inflammation in the brain are mediated by the endothelial cell mineralocorticoid receptor. Brain Res. 2016, 1637, 146-153. [CrossRef] [PubMed]

85. Rocha, R.; Rudolph, A.E.; Frierdich, G.E.; Nachowiak, D.A.; Kekec, B.K.; Blomme, E.A.; McMahon, E.G.; Delyani, J.A. Aldosterone induces a vascular inflammatory phenotype in the rat heart. Am. J. Physiol. Heart Circ. Physiol. 2002, 283, H1802-H1810. [CrossRef]

86. Nishimoto, M.; Fujita, T. Renal mechanisms of salt-sensitive hypertension: Contribution of two steroid receptor-associated pathways. Am. J. Physiol. Ren. Physiol. 2015, 308, F377-F387. [CrossRef]

87. Martinez, D.V.; Rocha, R.; Matsumura, M.; Oestreicher, E.; Ochoa-Maya, M.; Roubsanthisuk, W.; Williams, G.H.; Adler, G.K. Cardiac damage prevention by eplerenone: Comparison with low sodium diet or potassium loading. Hypertension 2002, 39, 614-618. [CrossRef]

88. Zhu, C.J.; Wang, Q.Q.; Zhou, J.L.; Liu, H.Z.; Hua, F.; Yang, H.Z.; Hu, Z.W. The mineralocorticoid receptor-p38mapk-nfkappab or erk-sp1 signal pathways mediate aldosterone-stimulated inflammatory and profibrotic responses in rat vascular smooth muscle cells. Acta Pharm. Sin 2012, 33, 873-878. [CrossRef]

89. Min, L.J.; Mogi, M.; Li, J.M.; Iwanami, J.; Iwai, M.; Horiuchi, M. Aldosterone and angiotensin ii synergistically induce mitogenic response in vascular smooth muscle cells. Circ. Res. 2005, 97, 434-442. [CrossRef]

90. Mazak, I.; Fiebeler, A.; Muller, D.N.; Park, J.K.; Shagdarsuren, E.; Lindschau, C.; Dechend, R.; Viedt, C.; Pilz, B.; Haller, H.; et al. Aldosterone potentiates angiotensin ii-induced signaling in vascular smooth muscle cells. Circulation 2004, 109, 2792-2800. [CrossRef]

91. Lemarie, C.A.; Simeone, S.M.; Nikonova, A.; Ebrahimian, T.; Deschenes, M.E.; Coffman, T.M.; Paradis, P.; Schiffrin, E.L. Aldosterone-induced activation of signaling pathways requires activity of angiotensin type 1a receptors. Circ. Res. 2009, 105, 852-859. [CrossRef] [PubMed]

92. Brown, N.J. Aldosterone and vascular inflammation. Hypertension 2008, 51, 161-167. [CrossRef] [PubMed]

93. Terada, Y.; Ueda, S.; Hamada, K.; Shimamura, Y.; Ogata, K.; Inoue, K.; Taniguchi, Y.; Kagawa, T.; Horino, T.; Takao, T. Aldosterone stimulates nuclear factor-kappa $\mathrm{b}$ activity and transcription of intercellular adhesion molecule- 1 and connective tissue growth factor in rat mesangial cells via serum- and glucocorticoid-inducible protein kinase-1. Clin. Exp. Nephrol. 2012, 16, 81-88. [CrossRef] [PubMed]

94. Blasi, E.R.; Rocha, R.; Rudolph, A.E.; Blomme, E.A.; Polly, M.L.; McMahon, E.G. Aldosterone/salt induces renal inflammation and fibrosis in hypertensive rats. Kidney Int. 2003, 63, 1791-1800. [CrossRef] [PubMed]

95. Caprio, M.; Newfell, B.G.; la Sala, A.; Baur, W.; Fabbri, A.; Rosano, G.; Mendelsohn, M.E.; Jaffe, I.Z. Functional mineralocorticoid receptors in human vascular endothelial cells regulate intercellular adhesion molecule-1 expression and promote leukocyte adhesion. Circ. Res. 2008, 102, 1359-1367. [CrossRef]

96. Wong, S.; Brennan, F.E.; Young, M.J.; Fuller, P.J.; Cole, T.J. A direct effect of aldosterone on endothelin-1 gene expression in vivo. Endocrinology 2007, 148, 1511-1517. [CrossRef] 
97. Li, L.; Fink, G.D.; Watts, S.W.; Northcott, C.A.; Galligan, J.J.; Pagano, P.J.; Chen, A.F. Endothelin-1 increases vascular superoxide via endothelin(a)-nadph oxidase pathway in low-renin hypertension. Circulation 2003, 107, 1053-1058. [CrossRef]

98. Jeong, Y.; Chaupin, D.F.; Matsushita, K.; Yamakuchi, M.; Cameron, S.J.; Morrell, C.N.; Lowenstein, C.J. Aldosterone activates endothelial exocytosis. Proc. Natl. Acad. Sci. USA 2009, 106, 3782-3787. [CrossRef]

99. Kirsch, T.; Beese, M.; Wyss, K.; Klinge, U.; Haller, H.; Haubitz, M.; Fiebeler, A. Aldosterone modulates endothelial permeability and endothelial nitric oxide synthase activity by rearrangement of the actin cytoskeleton. Hypertension 2013, 61, 501-508. [CrossRef]

100. Cathcart, M.K. Regulation of superoxide anion production by nadph oxidase in monocytes/macrophages: Contributions to atherosclerosis. Arterioscler. Thromb. Vasc. Biol. 2004, 24, 23-28. [CrossRef]

101. Dragoni, S.; Hudson, N.; Kenny, B.A.; Burgoyne, T.; McKenzie, J.A.; Gill, Y.; Blaber, R.; Futter, C.E.; Adamson, P.; Greenwood, J.; et al. Endothelial mapks direct icam-1 signaling to divergent inflammatory functions. J. Immunol. 2017, 198, 4074-4085. [CrossRef] [PubMed]

102. Baumgartner-Parzer, S.M.; Waldhausl, W.K. The endothelium as a metabolic and endocrine organ: Its relation with insulin resistance. Exp. Clin. Endocrinol. Diabetes 2001, 109 (Suppl. 2), S166-S179. [CrossRef] [PubMed]

103. Galley, H.F.; Webster, N.R. Physiology of the endothelium. Br. J. Anaesth. 2004, 93, 105-113. [CrossRef] [PubMed]

104. Chou, C.H.; Hung, C.S.; Liao, C.W.; Wei, L.H.; Chen, C.W.; Shun, C.T.; Wen, W.F.; Wan, C.H.; Wu, X.M.; Chang, Y.Y.; et al. Il-6 trans-signalling contributes to aldosterone-induced cardiac fibrosis. Cardiovasc. Res. 2018, 114, 690-702. [CrossRef] [PubMed]

105. Sturgis, L.C.; Cannon, J.G.; Schreihofer, D.A.; Brands, M.W. The role of aldosterone in mediating the dependence of angiotensin hypertension on il-6. Am. J. Physiol. Regul. Integr. Comp. Physiol. 2009, 297, R1742-R1748. [CrossRef] [PubMed]

106. Luther, J.M.; Gainer, J.V.; Murphey, L.J.; Yu, C.; Vaughan, D.E.; Morrow, J.D.; Brown, N.J. Angiotensin ii induces interleukin-6 in humans through a mineralocorticoid receptor-dependent mechanism. Hypertension 2006, 48, 1050-1057. [CrossRef]

107. Lim, J.S.; Park, S.; Park, S.I.; Oh, Y.T.; Choi, E.; Kim, J.Y.; Rhee, Y. Cardiac dysfunction in association with increased inflammatory markers in primary aldosteronism. Endocrinol. Metab. 2016, 31, 567-576. [CrossRef]

108. Sanz-Rosa, D.; Cediel, E.; de las Heras, N.; Miana, M.; Balfagon, G.; Lahera, V.; Cachofeiro, V. Participation of aldosterone in the vascular inflammatory response of spontaneously hypertensive rats: Role of the nfkappab/ikappab system. J. Hypertens. 2005, 23, 1167-1172. [CrossRef]

109. Davignon, J.; Ganz, P. Role of endothelial dysfunction in atherosclerosis. Circulation 2004, 109, III-27-III-32. [CrossRef]

110. Chhabra, R.K. Endothelial Dysfunction-A Predictor of Atherosclerosis. Internet J. Med. Update 2009, 4. [CrossRef]

111. Hillaert, M.A.; Lentjes, E.G.; Beygui, F.; Kemperman, H.; Asselbergs, F.W.; Nathoe, H.M.; Agostoni, P.; Voskuil, M.; Ivanes, F.; Jude, B.; et al. Measuring and targeting aldosterone and renin in atherosclerosis-a review of clinical data. Am. Heart J. 2011, 162, 585-596. [CrossRef] [PubMed]

112. Gilbert, K.C.; Brown, N.J. Aldosterone and inflammation. Curr. Opin. Endocrinol. Diabetes Obes. 2010, 17, 199-204. [CrossRef] [PubMed]

113. Mudau, M.; Genis, A.; Lochner, A.; Strijdom, H. Endothelial dysfunction: The early predictor of atherosclerosis. Cardiovasc. J. Afr. 2012, 23, 222-231. [CrossRef] [PubMed]

114. Van Belle, E.; Bauters, C.; Wernert, N.; Hamon, M.; McFadden, E.P.; Racadot, A.; Dupuis, B.; Lablanche, J.M.; Bertrand, M.E. Neointimal thickening after balloon denudation is enhanced by aldosterone and inhibited by spironolactone, and aldosterone antagonist. Cardiovasc. Res. 1995, 29, 27-32. [CrossRef]

115. Keidar, S.; Hayek, T.; Kaplan, M.; Pavlotzky, E.; Hamoud, S.; Coleman, R.; Aviram, M. Effect of eplerenone, a selective aldosterone blocker, on blood pressure, serum and macrophage oxidative stress, and atherosclerosis in apolipoprotein e-deficient mice. J. Cardiovasc. Pharmacol. 2003, 41, 955-963. [CrossRef]

116. Keidar, S.; Kaplan, M.; Pavlotzky, E.; Coleman, R.; Hayek, T.; Hamoud, S.; Aviram, M. Aldosterone administration to mice stimulates macrophage nadph oxidase and increases atherosclerosis development: A possible role for angiotensin-converting enzyme and the receptors for angiotensin ii and aldosterone. Circulation 2004, 109, 2213-2220. [CrossRef] 
117. Suzuki, J.; Iwai, M.; Mogi, M.; Oshita, A.; Yoshii, T.; Higaki, J.; Horiuchi, M. Eplerenone with valsartan effectively reduces atherosclerotic lesion by attenuation of oxidative stress and inflammation. Arterioscler. Thromb. Vasc. Biol. 2006, 26, 917-921. [CrossRef]

118. Imanishi, T.; Ikejima, H.; Tsujioka, H.; Kuroi, A.; Kobayashi, K.; Muragaki, Y.; Mochizuki, S.; Goto, M.; Yoshida, K.; Akasaka, T. Addition of eplerenone to an angiotensin-converting enzyme inhibitor effectively improves nitric oxide bioavailability. Hypertension 2008, 51, 734-741. [CrossRef]

119. Marzolla, V.; Armani, A.; Mammi, C.; Moss, M.E.; Pagliarini, V.; Pontecorvo, L.; Antelmi, A.; Fabbri, A.; Rosano, G.; Jaffe, I.Z.; et al. Essential role of icam-1 in aldosterone-induced atherosclerosis. Int. J. Cardiol. 2017, 232, 233-242. [CrossRef]

120. McGraw, A.P.; Bagley, J.; Chen, W.S.; Galayda, C.; Nickerson, H.; Armani, A.; Caprio, M.; Carmeliet, P.; Jaffe, I.Z. Aldosterone increases early atherosclerosis and promotes plaque inflammation through a placental growth factor-dependent mechanism. J. Am. Heart Assoc. 2013, 2, e000018. [CrossRef]

121. McCurley, A.; Jaffe, I.Z. Mineralocorticoid receptors in vascular function and disease. Mol. Cell Endocrinol. 2012, 350, 256-265. [CrossRef] [PubMed]

122. Wakabayashi, K.; Suzuki, H.; Sato, T.; Iso, Y.; Katagiri, T.; Takeyama, Y. Eplerenone suppresses neointimal formation after coronary stent implantation in swine. Int. J. Cardiol. 2006, 107, 260-266. [CrossRef] [PubMed]

123. Pu, Q.; Neves, M.F.; Virdis, A.; Touyz, R.M.; Schiffrin, E.L. Endothelin antagonism on aldosterone-induced oxidative stress and vascular remodeling. Hypertension 2003, 42, 49-55. [CrossRef] [PubMed]

124. Nguyen Dinh Cat, A.; Griol-Charhbili, V.; Loufrani, L.; Labat, C.; Benjamin, L.; Farman, N.; Lacolley, P.; Henrion, D.; Jaisser, F. The endothelial mineralocorticoid receptor regulates vasoconstrictor tone and blood pressure. Faseb J. Off. Publ. Fed. Am. Soc. Exp. Biol. 2010, 24, 2454-2463.

125. Schafer, N.; Lohmann, C.; Winnik, S.; van Tits, L.J.; Miranda, M.X.; Vergopoulos, A.; Ruschitzka, F.; Nussberger, J.; Berger, S.; Luscher, T.F.; et al. Endothelial mineralocorticoid receptor activation mediates endothelial dysfunction in diet-induced obesity. Eur. Heart J. 2013, 34, 3515-3524. [CrossRef] [PubMed]

126. Rickard, A.J.; Morgan, J.; Chrissobolis, S.; Miller, A.A.; Sobey, C.G.; Young, M.J. Endothelial cell mineralocorticoid receptors regulate deoxycorticosterone/salt-mediated cardiac remodeling and vascular reactivity but not blood pressure. Hypertension 2014, 63, 1033-1040. [CrossRef] [PubMed]

127. Werner, N.; Kosiol, S.; Schiegl, T.; Ahlers, P.; Walenta, K.; Link, A.; Böhm, M.; Nickenig, G. Circulating endothelial progenitor cells and cardiovascular outcomes. New Engl. J. Med. 2005, 353, 999-1007. [CrossRef]

128. Schmidt-Lucke, C.; Rossig, L.; Fichtlscherer, S.; Vasa, M.; Britten, M.; Kamper, U.; Dimmeler, S.; Zeiher, A.M. Reduced number of circulating endothelial progenitor cells predicts future cardiovascular events: Proof of concept for the clinical importance of endogenous vascular repair. Circulation 2005, 111, 2981-2987. [CrossRef]

129. Verhovez, A.; Zeoli, A.; Williams, T.A.; Morello, F.; Brizzi, M.F.; Veglio, F.; Mulatero, P. Primary aldosteronism (pa) and endothelial progenitor cell (epc) bioavailability. Clin. Endocrinol. 2008, 69, 528-534. [CrossRef]

130. Thum, T.; Schmitter, K.; Fleissner, F.; Wiebking, V.; Dietrich, B.; Widder, J.D.; Jazbutyte, V.; Hahner, S.; Ertl, G.; Bauersachs, J. Impairment of endothelial progenitor cell function and vascularization capacity by aldosterone in mice and humans. Eur. Heart J. 2011, 32, 1275-1286. [CrossRef]

131. Wu, V.C.; Lo, S.C.; Chen, Y.L.; Huang, P.H.; Tsai, C.T.; Liang, C.J.; Kuo, C.C.; Kuo, Y.S.; Lee, B.C.; Wu, E.L.; et al. Endothelial progenitor cells in primary aldosteronism: A biomarker of severity for aldosterone vasculopathy and prognosis. J. Clin. Endocrinol. Metab. 2011, 96, 3175-3183. [CrossRef] [PubMed]

132. DuPont, J.J.; Hill, M.A.; Bender, S.B.; Jaisser, F.; Jaffe, I.Z. Aldosterone and vascular mineralocorticoid receptors: Regulators of ion channels beyond the kidney. Hypertension 2014, 63, 632-637. [CrossRef] [PubMed]

133. Nesterov, V.; Dahlmann, A.; Krueger, B.; Bertog, M.; Loffing, J.; Korbmacher, C. Aldosterone-dependent and -independent regulation of the epithelial sodium channel (enac) in mouse distal nephron. Am. J. Physiol. Ren. Physiol. 2012, 303, F1289-F1299. [CrossRef] [PubMed]

134. Kusche-Vihrog, K.; Sobczak, K.; Bangel, N.; Wilhelmi, M.; Nechyporuk-Zloy, V.; Schwab, A.; Schillers, H.; Oberleithner, H. Aldosterone and amiloride alter enac abundance in vascular endothelium. Pflug. Arch. Eur. J. Physiol. 2008, 455, 849-857. [CrossRef]

135. Kusche-Vihrog, K.; Jeggle, P.; Oberleithner, H. The role of enac in vascular endothelium. Pflug. Arch. Eur. J. Physiol. 2014, 466, 851-859. [CrossRef] 
136. Druppel, V.; Kusche-Vihrog, K.; Grossmann, C.; Gekle, M.; Kasprzak, B.; Brand, E.; Pavenstadt, H.; Oberleithner, H.; Kliche, K. Long-term application of the aldosterone antagonist spironolactone prevents stiff endothelial cell syndrome. FASEB J. Off. Publ. Fed. Am. Soc. Exp. Biol. 2013, 27, 3652-3659. [CrossRef]

137. Jia, G.; Habibi, J.; Aroor, A.R.; Hill, M.A.; Yang, Y.; Whaley-Connell, A.; Jaisser, F.; Sowers, J.R. Epithelial sodium channel in aldosterone-induced endothelium stiffness and aortic dysfunction. Hypertension 2018, 72, 731-738. [CrossRef]

138. Wulff, H.; Kohler, R. Endothelial small-conductance and intermediate-conductance kca channels: An update on their pharmacology and usefulness as cardiovascular targets. J. Cardiovasc. Pharmacol. 2013, 61, 102-112. [CrossRef]

139. Dora, K.A.; Gallagher, N.T.; McNeish, A.; Garland, C.J. Modulation of endothelial cell kca3.1 channels during endothelium-derived hyperpolarizing factor signaling in mesenteric resistance arteries. Circ. Res. 2008, 102, 1247-1255. [CrossRef]

140. Ledoux, J.; Taylor, M.S.; Bonev, A.D.; Hannah, R.M.; Solodushko, V.; Shui, B.; Tallini, Y.; Kotlikoff, M.I.; Nelson, M.T. Functional architecture of inositol 1,4,5-trisphosphate signaling in restricted spaces of myoendothelial projections. Proc. Natl. Acad. Sci. USA 2008, 105, 9627-9632. [CrossRef]

141. Saliez, J.; Bouzin, C.; Rath, G.; Ghisdal, P.; Desjardins, F.; Rezzani, R.; Rodella, L.F.; Vriens, J.; Nilius, B.; Feron, O.; et al. Role of caveolar compartmentation in endothelium-derived hyperpolarizing factor-mediated relaxation: Ca2+ signals and gap junction function are regulated by caveolin in endothelial cells. Circulation 2008, 117, 1065-1074. [CrossRef] [PubMed]

142. Brahler, S.; Kaistha, A.; Schmidt, V.J.; Wolfle, S.E.; Busch, C.; Kaistha, B.P.; Kacik, M.; Hasenau, A.L.; Grgic, I.; $\mathrm{Si}, \mathrm{H} . ;$ et al. Genetic deficit of sk3 and ik1 channels disrupts the endothelium-derived hyperpolarizing factor vasodilator pathway and causes hypertension. Circulation 2009, 119, 2323-2332. [CrossRef] [PubMed]

143. Taylor, M.S.; Bonev, A.D.; Gross, T.P.; Eckman, D.M.; Brayden, J.E.; Bond, C.T.; Adelman, J.P.; Nelson, M.T. Altered expression of small-conductance ca2+-activated k+ (sk3) channels modulates arterial tone and blood pressure. Circ. Res. 2003, 93, 124-131. [CrossRef] [PubMed]

144. Kohler, R.; Ruth, P. Endothelial dysfunction and blood pressure alterations in k+-channel transgenic mice. Pflug. Arch. Eur. J. Physiol. 2010, 459, 969-976. [CrossRef] [PubMed]

145. Zhao, M.; Celerier, I.; Bousquet, E.; Jeanny, J.C.; Jonet, L.; Savoldelli, M.; Offret, O.; Curan, A.; Farman, N.; Jaisser, F.; et al. Mineralocorticoid receptor is involved in rat and human ocular chorioretinopathy. J. Clin. Investig. 2012, 122, 2672-2679. [CrossRef]

146. Raposo, G.; Stoorvogel, W. Extracellular vesicles: Exosomes, microvesicles, and friends. J. Cell Biol. 2013, 200, 373-383. [CrossRef]

147. van Niel, G.; D’Angelo, G.; Raposo, G. Shedding light on the cell biology of extracellular vesicles. Nat. Rev. Mol. Cell Biol. 2018, 19, 213-228. [CrossRef]

148. Gould, S.J.; Raposo, G. As we wait: Coping with an imperfect nomenclature for extracellular vesicles. J. Extracell. Vesicles 2013, 2. [CrossRef]

149. Neves, K.B.; Rios, F.J.; Jones, R.; Evans, T.R.J.; Montezano, A.C.; Touyz, R.M. Microparticles from vascular endothelial growth factor pathway inhibitor-treated cancer patients mediate endothelial cell injury. Cardiovasc. Res. 2019, 115, 978-988. [CrossRef]

150. Lopez Andres, N.; Tesse, A.; Regnault, V.; Louis, H.; Cattan, V.; Thornton, S.N.; Labat, C.; Kakou, A.; Tual-Chalot, S.; Faure, S.; et al. Increased microparticle production and impaired microvascular endothelial function in aldosterone-salt-treated rats: Protective effects of polyphenols. PLoS ONE 2012, 7, e39235. [CrossRef]

151. Burger, D.; Kwart, D.G.; Montezano, A.C.; Read, N.C.; Kennedy, C.R.J.; Thompson, C.S.; Touyz, R.M. Microparticles induce cell cycle arrest through redox-sensitive processes in endothelial cells: Implications in vascular senescence. J. Am. Heart Assoc. 2012, 1, e001842. [CrossRef] [PubMed]

152. Burrello, J.; Gai, C.; Tetti, M.; Lopatina, T.; Deregibus, M.C.; Veglio, F.; Mulatero, P.; Camussi, G.; Monticone, S. Characterization and gene expression analysis of serum-derived extracellular vesicles in primary aldosteronism. Hypertension 2019, 74, 359-367. [CrossRef] [PubMed]

153. Neves, K.B.; Touyz, R.M. Extracellular vesicles as biomarkers and biovectors in primary aldosteronism. Hypertension 2019, 74, 250-252. [CrossRef] [PubMed]

154. Taddei, S.; Virdis, A.; Mattei, P.; Salvetti, A. Vasodilation to acetylcholine in primary and secondary forms of human hypertension. Hypertension 1993, 21, 929-933. [CrossRef] [PubMed] 
155. Farquharson, C.A.; Struthers, A.D. Aldosterone induces acute endothelial dysfunction in vivo in humans: Evidence for an aldosterone-induced vasculopathy. Clin. Sci. 2002, 103, 425-431. [CrossRef]

156. Farquharson, C.A.; Struthers, A.D. Spironolactone increases nitric oxide bioactivity, improves endothelial vasodilator dysfunction, and suppresses vascular angiotensin $\mathrm{i} /$ angiotensin ii conversion in patients with chronic heart failure. Circulation 2000, 101, 594-597. [CrossRef]

157. Macdonald, J.E.; Kennedy, N.; Struthers, A.D. Effects of spironolactone on endothelial function, vascular angiotensin converting enzyme activity, and other prognostic markers in patients with mild heart failure already taking optimal treatment. Heart 2004, 90, 765-770. [CrossRef]

158. Deanfield, J.E.; Halcox, J.P.; Rabelink, T.J. Endothelial function and dysfunction: Testing and clinical relevance. Circulation 2007, 115, 1285-1295. [CrossRef]

159. Al-Qaisi, M.; Kharbanda, R.K.; Mittal, T.K.; Donald, A.E. Measurement of endothelial function and its clinical utility for cardiovascular risk. Vasc. Health Risk Manag. 2008, 4, 647-652. [CrossRef]

160. Flammer, A.J.; Anderson, T.; Celermajer, D.S.; Creager, M.A.; Deanfield, J.; Ganz, P.; Hamburg, N.M.; Luscher, T.F.; Shechter, M.; Taddei, S.; et al. The assessment of endothelial function: From research into clinical practice. Circulation 2012, 126, 753-767. [CrossRef]

161. Matrozova, J.; Vasilev, V.; Vandeva, S.; Elenkova, A.; Kirilov, G.; Zaharieva, S. Asymmetric dimethylarginin (adma) as a marker of endothelial dysfunction in primary aldosteronism. Int. J. Endocrinol. Metab. 2016, 14, e30324. [CrossRef] [PubMed]

162. Liu, G.; Yin, G.S.; Tang, J.Y.; Ma, D.J.; Ru, J.; Huang, X.H. Endothelial dysfunction in patients with primary aldosteronism: A biomarker of target organ damage. J. Hum. Hypertens. 2014, 28, 711-715. [CrossRef] [PubMed]

163. Nishizaka, M.K.; Zaman, M.A.; Green, S.A.; Renfroe, K.Y.; Calhoun, D.A. Impaired endothelium-dependent flow-mediated vasodilation in hypertensive subjects with hyperaldosteronism. Circulation 2004, 109, 2857-2861. [CrossRef] [PubMed]

164. Lai, S.; Petramala, L.; Mastroluca, D.; Petraglia, E.; Di Gaeta, A.; Indino, E.; Panebianco, V.; Ciccariello, M.; Shahabadi, H.H.; Galani, A.; et al. Hyperaldosteronism and cardiovascular risk in patients with autosomal dominant polycystic kidney disease. Medicine 2016, 95, e4175. [CrossRef] [PubMed]

165. Chou, C.H.; Chen, Y.H.; Hung, C.S.; Chang, Y.Y.; Tzeng, Y.L.; Wu, X.M.; Wu, V.C.; Tsai, C.T.; Wu, C.K.; Ho, Y.L.; et al. Aldosterone impairs vascular smooth muscle function: From clinical to bench research. J. Clin. Endocrinol. Metab. 2015, 100, 4339-4347. [CrossRef] [PubMed]

166. Kishimoto, S.; Matsumoto, T.; Oki, K.; Maruhashi, T.; Kajikawa, M.; Matsui, S.; Hashimoto, H.; Kihara, Y.; Yusoff, F.M.; Higashi, Y. Microvascular endothelial function is impaired in patients with idiopathic hyperaldosteronism. Hypertens Res 2018, 41, 932-938. [CrossRef]

167. Chang, Y.Y.; Chen, A.; Chen, Y.H.; Hung, C.S.; Wu, V.C.; Wu, X.M.; Lin, Y.H.; Ho, Y.L.; Wu, K.D.; Group, T.S. Hypokalemia correlated with arterial stiffness but not microvascular endothelial function in patients with primary aldosteronism. J. Renin-Angiotensin-Aldosterone Syst. JRAAS 2015, 16, 353-359. [CrossRef]

168. Bernini, G.; Galetta, F.; Franzoni, F.; Bardini, M.; Taurino, C.; Bernardini, M.; Ghiadoni, L.; Bernini, M.; Santoro, G.; Salvetti, A. Arterial stiffness, intima-media thickness and carotid artery fibrosis in patients with primary aldosteronism. J Hypertens. 2008, 26, 2399-2405. [CrossRef]

169. Strauch, B.; Petrak, O.; Wichterle, D.; Zelinka, T.; Holaj, R.; Widimsky, J., Jr. Increased arterial wall stiffness in primary aldosteronism in comparison with essential hypertension. Am. J. Hypertens. 2006, 19, 909-914. [CrossRef]

170. Strauch, B.; Petrak, O.; Zelinka, T.; Wichterle, D.; Holaj, R.; Kasalicky, M.; Safarik, L.; Rosa, J.; Widimsky, J., Jr. Adrenalectomy improves arterial stiffness in primary aldosteronism. Am. J. Hypertens. 2008, 21, 1086-1092. [CrossRef]

171. Rosa, J.; Somloova, Z.; Petrak, O.; Strauch, B.; Indra, T.; Senitko, M.; Zelinka, T.; Holaj, R.; Widimsky, J., Jr. Peripheral arterial stiffness in primary aldosteronism. Physiol. Res. 2012, 61, 461-468. [CrossRef] [PubMed]

172. Chang, C.H.; Hu, Y.H.; Tsai, Y.C.; Wu, C.H.; Wang, S.M.; Lin, L.Y.; Lin, Y.H.; Satoh, F.; Wu, K.D.; Wu, V.C. Arterial stiffness and blood pressure improvement in aldosterone-producing adenoma harboring kcnj5 mutations after adrenalectomy. Oncotarget 2017, 8, 29984-29995. [CrossRef] [PubMed]

173. Moerland, M.; Kales, A.J.; Schrier, L.; van Dongen, M.G.J.; Bradnock, D.; Burggraaf, J. Evaluation of the endopat as a tool to assess endothelial function. Int. J. Vasc. Med. 2012, 2012, 8. [CrossRef] [PubMed] 
174. Kato, T.; Node, K. Microvascular and macrovascular endothelial function in two different types of primary aldosteronism. Hypertens Res 2019, 42, 739-740. [CrossRef]

175. Verdecchia, P.; Angeli, F.; Taddei, S. At the beginning of stiffening: Endothelial dysfunction meets "pulsology". Hypertension 2006, 48, 541-542. [CrossRef]

176. McEniery, C.M.; Wallace, S.; Mackenzie, I.S.; McDonnell, B.; Yasmin; Newby, D.E.; Cockcroft, J.R.; Wilkinson, I.B. Endothelial function is associated with pulse pressure, pulse wave velocity, and augmentation index in healthy humans. Hypertension 2006, 48, 602-608. [CrossRef]

177. Naka, K.K.; Tweddel, A.C.; Doshi, S.N.; Goodfellow, J.; Henderson, A.H. Flow-mediated changes in pulse wave velocity: A new clinical measure of endothelial function. Eur. Heart J. 2006, 27, 302-309. [CrossRef]

178. Williams, T.A.; Monticone, S.; Mulatero, P. Kcnj5 mutations are the most frequent genetic alteration in primary aldosteronism. Hypertension 2015, 65, 507-509. [CrossRef]

179. Lenzini, L.; Rossitto, G.; Maiolino, G.; Letizia, C.; Funder, J.W.; Rossi, G.P. A meta-analysis of somatic kcnj5 $\mathrm{k}(+)$ channel mutations in 1636 patients with an aldosterone-producing adenoma. J. Clin. Endocrinol. Metab. 2015, 100, E1089-E1095. [CrossRef]

(C) 2019 by the authors. Licensee MDPI, Basel, Switzerland. This article is an open access article distributed under the terms and conditions of the Creative Commons Attribution (CC BY) license (http://creativecommons.org/licenses/by/4.0/). 